\title{
BMI1 Sustains Human Glioblastoma Multiforme Stem Cell Renewal
}

\author{
Mohamed Abdouh, ${ }^{1 *}$ Sabrina Facchino, ${ }^{1 *}$ Wassim Chatoo, ${ }^{1}$ Vijayabalan Balasingam, ${ }^{2}$ José Ferreira, ${ }^{3}$ \\ and Gilbert Bernier ${ }^{1,4}$ \\ ${ }^{1}$ Developmental Biology Laboratory, and Departments of ${ }^{2}$ Surgery and ${ }^{3}$ Pathology, Maisonneuve-Rosemont Hospital, Montréal, Québec H1T 2M4, Canada, \\ and ${ }^{4}$ Department of Ophthalmology, University of Montréal, Montréal, Québec H3T 1J4, Canada
}

Glioblastoma multiforme (GBM) is one of the most common and aggressive types of brain tumors. In GBM, a subpopulation of CD133positive cancer initiating cells displays stem cell characteristics. The Polycomb group (PcG) and oncogene BMI1 is part of the Polycomb repressive complex 1 (PRC1) that regulates gene expression by modifying chromatin organization. Here we show that BMI1 is expressed in human GBM tumors and highly enriched in CD133-positive cells. Stable BMI1 knockdown using short hairpin RNA-expressing lentiviruses resulted in inhibition of clonogenic potential in vitro and of brain tumor formation in vivo. Cell biology studies support the notion that BMI1 prevents CD133-positive cell apoptosis and/or differentiation into neurons and astrocytes, depending on the cellular context. Gene expression analyses suggest that BMI1 represses alternate tumor suppressor pathways that attempt to compensate for INK4A/ARF/P53 deletion and PI(3)K/AKT hyperactivity. Inhibition of EZH2, the main component of the PRC2, also impaired GBM tumor growth. Our results reveal that PcG proteins are involved in GBM tumor growth and required to sustain cancer initiating stem cell renewal.

\section{Introduction}

Glioblastoma multiforme (GBM) is the most common and deadly brain tumor. There are two subtypes of GBM. Primary GBM arises without evidence of previous clinical disease, whereas secondary GBM derives from preexisting low-grade lesions (Maher et al., 2001; Louis et al., 2007). Notably, the prognosis has not changed significantly for decades, with a median survival of less than one year (Holland, 2001; Maher et al., 2001). A better understanding of GBM molecular genetics will reveal the mechanisms underlying the initiation and progression of the disease, and open new gates to develop therapeutic strategies.

Polycomb group ( $\mathrm{PcG}$ ) proteins form large multimeric complexes that are involved in gene silencing through modifications of chromatin organization (Sparmann and van Lohuizen, 2006). They are classically subdivided into two groups, namely Polycomb Repressive Complex 1 (PRC1) and PRC2 (Levine et al., 2002). The sequential histone modifications induced by the PRC2 complex (which includes EZH2) and the PRC1 complex (which includes BMI1) allow stable silencing of gene expression (Dellino et al., 2004; Wang et al., 2004). A number of observa-

\footnotetext{
Received Feb. 24, 2009; revised March 31, 2009; accepted June 4, 2009.

This work is supported in part by grants from the Natural Science and Engineering Research Council of Canada, and Canadian Institutes of Health Research. G.B. is supported by the Fonds de Recherche en Santé du Québec. W.C. is a Scholar from the Fonds de Recherche en Ophthalmologie de I'Université de Montréal. We are grateful to the Brain Tumor Tissue Bank and the Brain Tumor Foundation of Canada for archival brain tumor sample supply. We thank Nathalie Hanley for assistance in flow cytometry cell sorting.

${ }^{*}$ M.A. and S.F. contributed equally to this work.

Correspondence should be addressed to Gilbert Bernier, Hôpital Maisonneuve-Rosemont, Centre de recherche, Pavillon Marcel-Lamoureux, 5415 boulevard de I'Assomption, Montréal, Québec H1T 2M4, Canada. E-mail: gbernier.hmr@ssss.gouv.qc.ca.

DOI:10.1523/JNEUROSCI.0968-09.2009

Copyright $\odot 2009$ Society for Neuroscience $\quad$ 0270-6474/09/298884-13\$15.00/0
}

tions have implicated these proto-oncogenes in human cancers (Orian et al., 1992; Lassman et al., 2004; Valk-Lingbeek et al., 2004). EZH2, the core component of the PRC2, is upregulated in lymphoma, prostate and breast cancer (van Kemenade et al., 2001; Visser et al., 2001; Varambally et al., 2002; Kleer et al., 2003). Bmil was originally identified as an oncogenic partner in lymphomagenesis, and was subsequently found to be overexpressed in various human cancers, including medulloblastomas (van Lohuizen et al., 1991; Haupt et al., 1991; Jacobs et al., 1999b; Vonlanthen et al., 2001; Dimri et al., 2002; Leung et al., 2004; Bruggeman et al., 2007). Mice lacking Bmil display neurological abnormalities and postnatal depletion of stem cells from the central and peripheral nervous systems (Jacobs et al., 1999a; Molofsky et al., 2003, 2005; Bruggeman et al., 2005; Zencak et al., 2005). Bmil is also required for the self-renewal of normal and leukemic stem cells (Lessard and Sauvageau, 2003; Park et al., 2003). Importantly, the $I N K 4 A / A R F$ locus, encoding for the two tumor suppressor proteins $\mathrm{p} 16^{\mathrm{INK} 4 \mathrm{~A}}$ and $\mathrm{p} 14^{\mathrm{ARF}}$, is the main target of BMI1 oncogenic and stem cell proliferation activities (Valk-Lingbeek et al., 2004).

Here we report that BMI1 and EZH2 are overexpressed in human GBM tumors and highly enriched in tumor-initiating $\mathrm{CD}_{133}{ }^{+}$stem cells. Ablation of BMI1 or EZH2 expression in GBM cell lines cultured as neurospheres inhibited their growth and clonogenic potential. These effects, which were independent of a functional INK $4 A / A R F$ locus, correlated with depletion of the $\mathrm{CD} 133^{+}$cell population because of increased apoptosis and differentiation. BMI1 knockdown also completely prevented brain tumor formation in mice, even when up to $1 \times 10^{5}$ cells were transplanted. Gene expression analyses suggest that BMI 1 represses alternate tumor suppressor pathways that attempt to 
compensate for INK4A/ARF/P53 deletion and PI(3)K/AKT hyperactivity. This work revealed that $\mathrm{PcG}$ proteins are required in human GBM to sustain cancer-initiating stem cell renewal.

\section{Materials and Methods}

GBM specimen. Paraffin-embedded archival primary GBMs were obtained from the department of pathology of the Maisonneuve-Rosemont Hospital, and the Brain Tumor Tissue Bank (Toronto, ON, Canada). Fresh tumors were obtained from consenting patients and used with permission of our institutes' ethical committee.

Cell cultures. Fresh GBM samples were processed for cell cultures within $1 \mathrm{~h}$ after reception. Tumor was washed and cut in small pieces before mechanical dissociation in oxygenated HBSS. Cell suspensions were passed over a $40 \mu \mathrm{m}$ filter mesh. After centrifugation, cells were resuspended in DMEM/ F12 medium (Invitrogen) containing $0.25 \%$ glucose, N2 and B27 supplements, Heparin ( $2 \mu \mathrm{g} / \mathrm{ml}$; Sigma), gentamicin ( $25 \mu \mathrm{g} / \mathrm{ml}$; Invitrogen), human recombinant FGF2 (10 ng/ml; Peprotech), and human recombinant EGF ( $20 \mathrm{ng} / \mathrm{ml}$; Sigma). Afterward, cultures were allowed to grow for 3 weeks to form spherical colonies (i.e., neurospheres). For passages, neurospheres were incubated in an enzyme free solution (Millipore Bioscience Research Reagents) at $37^{\circ} \mathrm{C}$ for $20 \mathrm{~min}$, and mechanically dissociated with a $20 \mathrm{G}$ needle. After trituration, the single cell suspension was plated in the same culture medium as stated before.

Short-hairpin RNA construction and lentiviral infection. Oligonucleotides were synthesized that consisted of sequence-specific nucleotides stretch designed to target the BMI1 ORF (BC_011652) oligo \#1 from 1061 to 1081; CCTAATACTTTCCAGATTGAT, oligo \#2 from 500 to 518; GCAgaaatgcatcgaacaa, oligo \#3 from 1051 to 1069; Aatggacatacctaatact, and oligo \#4 from 573 to 591; Ggtacttcattgatgccac - used as scramble (supplemental Fig. 1, available at www.jneurosci.org as supplemental material), or the EZH2 ORF (NM_001991) (oligo \#7 from 324 to 344; cggaaatcttaaaccaagaat — which we used in this study, oligo \#8 from 950 to 970; cccaacatagatggaccaaat, and oligo \#9 from 1544 to 1564; gctaggttaattgggaccaaa), followed by the loop sequence (TTCAAGAGA) and finally the reverse complements of the targeting sequences. The doublestranded short-hairpin RNA (shRNA) sequences were cloned downstream of the H1P promoter of the H1P-UbqC-HygroEGFP plasmid using Age1, SmaI, and XbaI cloning sites (Ivanova et al., 2006). The shRNA-expressing lentiviral plasmids were cotransfected with plasmids pCMVdR8.9 and pHCMV-G into 293FT packaging cells using Lipofectamine (Invitrogen) according to the manufacturer's instructions. Viral containing media were collected, filtered, and concentrated by ultracentrifugation. Viral titers were measured by serial dilution on $293 \mathrm{~T}$ cells followed by microscopic analysis $48 \mathrm{~h}$ later. For viral transduction, lentiviral vectors were added to dissociated cancer cells before plating. Hygromycin selection $(150 \mu \mathrm{g} / \mathrm{ml})$ was added $48 \mathrm{~h}$ later.

Cell differentiation assays. Neurospheres were picked-up and deposited in a chamber slides (Lab-tek) coated with poly-L-lysine $(0.5 \mathrm{mg} / \mathrm{ml})$ and laminin (10 ng/ml; Sigma), in DMEM/F12 medium supplemented with $0.25 \%$ glucose, N2 and B27 supplements, gentamicin $(25 \mu \mathrm{g} / \mathrm{ml})$, and $1 \%$ fetal bovine serum (Invitrogen). After $10 \mathrm{~d}$ culture, they attached and grew in monolayers. Cells were washed with PBS to remove residual floating cells and stained for differentiation markers.

Colony formation assay. After infection with the respective viruses for $48 \mathrm{~h}$, the selection was added. Three days later, cells were sorted for $\mathrm{CD} 133^{+}$cells by a FACSvantage (cell purity 95\%) and $5.000 \mathrm{CD} 133+$ cells were plated on a thin layer Matrigel substrate-treated 6 well plate (BD Bioscience) and allowed to grow to confluence ( $\sim 10 \mathrm{~d}$ for the control). Cultures were fixed in PBS containing 4\% PFA, and stained with cresyl violet. After washing, phase contrast micrographs were taken.

Immunolabeling. For fixation, tissues were immersed for $1 \mathrm{~h}$ at room temperature in $4 \%$ paraformaldehyde (PFA) $/ 3 \%$ sucrose in $0.1 \mathrm{~m}$ phosphate buffer, $\mathrm{pH}$ 7.4. Samples were washed three times in PBS, cryoprotected in PBS/30\% sucrose, and frozen in CRYOMATRIX embedding medium (CEM) (Thermo Fisher Scientific). Otherwise, tissues were fixed in $10 \%$ buffered formalin and embedded in paraffin according to standard protocols. Five- to $7-\mu \mathrm{m}$-thick sections were mounted on Super-Frost glass slides (Thermo Fisher Scientific) and processed for immunofluorescence or immunohistochemistry staining. For immunofluorescence labeling, sections were incubated overnight with primary antibody solutions at $4^{\circ} \mathrm{C}$ in a humidified chamber. After three washes in PBS, sections were incubated with secondary antibodies for $1 \mathrm{~h}$ at room temperature. Slides were mounted on coverslips in DAPI-containing mounting medium (Vector Laboratories). For immunohistochemistry labeling, slices were analyzed by using the Vectastain $\mathrm{ABC}$ kit (Vector Laboratories) according to the manufacturer instructions. Peroxidase substrates used are the Vector VIP (Pink) (Vector Laboratories), and DAB (brown) (Sigma). Observations were made under a fluorescence microscope (Leica DMRE) and images were captured with a digital camera (Retiga EX; QImaging with OpenLab, version 3.1.1 software). Antibodies used in this study were mouse anti-mouse BMI1, rabbit antihuman EZH2 (US Biological), mouse anti-NeuN, rabbit anti-MAP2, mouse anti-human nuclei (Millipore Bioscience Research Reagents), mouse anti-CD133 (AC133) (Miltenyi Biotec), mouse anti-PCNA, rabbit anti-GFAP (DAKO), rabbit anti-Ki67 (Novocastra), mouse anti-GFP, mouse anti-mitochondria (Abcam), rabbit anti-activated caspase 3 (Cell Signaling Technology), rat anti-CD31 (PECAM-1) (BD Biosciences Pharmingen), and mouse anti-Nestin (BD Transduction Laboratory). For immunofluorescence, the secondary antibodies used were rhodamine-conjugated donkey anti-mouse, FITC-conjugated donkey anti-mouse, and FITCconjugated goat anti-rat (Millipore Bioscience Research Reagents).

Reverse-transcription PCR. All primers were designed to flank individual exons and tested by PCR in $\mathrm{RT}^{+}$and $\mathrm{RT}^{-}$control extracts. Total RNA was isolated using TRIzol reagent (Invitrogen). Reverse transcription (RT) was performed using $1 \mu \mathrm{g}$ of total RNA and the MML-V reverse transcriptase (Invitrogen). PCR amplification was performed using the HotStar TAQ polymerase (Invitrogen). PCR was run as follows: $94^{\circ} \mathrm{C}$ for $10 \mathrm{~min}$, followed by 30 cycles of denaturing at $94^{\circ} \mathrm{C}$, annealing at $57^{\circ} \mathrm{C}$ and extension at $72^{\circ} \mathrm{C}$ in a Applied Biosystems thermal cycler. Realtime PCR was performed using the Platinum SYBRGreen SuperMix (Invitrogen) and a real-time PCR apparatus (ABI Prism 7000). Primer sets used were as follows: BMIl forward (F) 5'-AATCCCCACCTGATGTGTGT-3'; reverse (R) 5'-GCTGGTCTCCAGGTAACGAA-3', Musashi (F) 5'-GTTTCGGCTTCGTCACTTTC-3'; (R) 5'-AAGGCCACCTTAGGGTCAAT-3', SOX2 (F) 5'-CACAACTCGGAGATCAGCAA-3'; (R) 5' CGGGGCCGGTATTTATAATC-3' , LHX2 (F) 5' -CCAAGGACTTGAAGCAGCTC-3'; (R) 5' -TAAGAGGTTGCGCCTGAACT-3', CD133 (F) 5' TTGTGGCAAATCACCAGGTA-3'; (R) 5'-TCAGATCTGTGAACGCCTTG-3', EZH2 (F) 5'-AGGACGGCTCCTCTAACCAT-3'; (R) 5' CTTGGTGTTGCACTGTGCTT-3', p21/Cip (F) 5'-ccgaagtcagttccttgtgg3'; p21/Cip (R) 5' -gtcgaagttccatcgctcac-3', HLA-DRB4 (F) 5'-ACAACTACGGGGTTGTGGAG-3'; (R) 5'-CGGAACCACCTGACTTCAAT-3', HLA-DPA1 (F) 5'-TTGGCTTTCCTGCTGAGTCT-3'; (R) 5'-CCCTGTTGGTCTATGCGTCT-3', HLA-DRA (F) 5'-AGACAAGTTCACCCCACCAG-3'; (R) 5' -AGCATCAAACTCCCAGTGCT-3', HLA-DMA (F) 5'-TACGACGAGGACCAGCTTTT-3'; (R) 5' -GCGTGAACACTTCAGCGATA-3', FOXO3A (F) 5'-acaaacggctcactctgtcc-3'; (R) 5'-tcttgccagttccctcattc- $3^{\prime}$, p18 (F) $5^{\prime}$-gcgctgcaggttatgaaac- $3^{\prime}$; (R) $5^{\prime}$-gggcaggttcccttcattat-3', PCNA (F) 5'-ggcgtgaacctcaccagtat-3'; (R) $5^{\prime}$-tcactccgtcttttgcacag-3', GAPDH (F) 5' -TCACCAGGGCTGCTTTTAAC-3'; (R) 5' ATCCACAGTCTTCTGGGTGG-3'. GAPDH was used as an internal standard for data calibration. The $2^{-\Delta \Delta \mathrm{Ct}}$ formula was used for the calculation of differential gene expression.

Gene amplification analysis. Genomique DNA was isolated using TRIzol reagent according to the protocol provided (Invitrogen). Quantitative PCR amplification was performed using the Platinum SYBRGreen SuperMix (Invitrogen) and Applied Biosystems 7000 RealTime PCR System. We evaluated loci copy number in each sample by comparison to the reference $\beta$-actin gene. We also choose PAX6 gene as another reference gene so as to confirm reliability of this qPCR assay. Primer sets used were as follows: BMI1 (F) 5'-TGTGTGCTTTGTGGAGGGTA-3'; (R) 5'-CATTTCCACAGATTGCAGGA-3', PAX6 (F) 5'-ACCACACCGGGTAATTTGAA-3'; (R) 5'-GCCAGATGTGAAGGAGGAAA-3', EGF-R (F) 5'-GCTAACGTGCAGGGATTGTT-3'; (R) 5'-GTTGAGGGCAATGAGGACAT-3', PDGF-R (F) 5' -ATGCTCTCCAGTGGCAGTTT-3'; (R) 5'-TGCACTGCAACCTTGAACTC-3', INK/ARF locus (F) 5' -TGGAAATCCTGAGGTTGGTC-3'; (R) 5'-ACT 
GCG GAG CAA TGA AGA CT-3', and $\beta$-actin (F) 5'-CTCTTCCAGC-

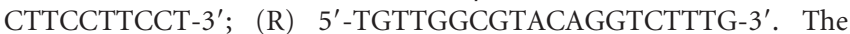
$2^{-\Delta \Delta C t}$ formula was used for the calculation of differential gene copy numbers. DNA from human retina was used as calibrator (gene copy $=2 \mathrm{~N}$ ).

Western blotting. Total protein extracts were prepared in the Complete Mini protease inhibitor cocktail solution (Roche Diagnostics). Proteins contents were quantified using the Bradford reagent. Proteins were resolved in Laemmli buffer by SDS-PAGE and transferred to a Nitrocellulose Blotting Membrane (Pall) that was exposed to the primary antibodies; mouse anti-mouse Bmil, rabbit anti-human EZH2 (US Biological), and mouse-anti $\beta$-actin (Abcam) antibodies. Membranes were treated with corresponding horseradish peroxidase-conjugated secondary antibodies (Sigma) and developed using the Immobilon Western (Millipore).

Fluorescence-activated cell sorting. For BMI1 expression analysis, single-cell suspension was fixed in 4\% paraformaldehyde for $20 \mathrm{~min}$ and permeabilized by incubation in $0.5 \%$ Triton X-100 for $5 \mathrm{~min}$ on ice. Cells were incubated with mouse anti BMI1 antibody (1.T.21, Abcam). The primary antibodies were visualized by using FITC-conjugated goat antimouse (Millipore Bioscience Research Reagents). Cells were acquired in a FACScan flow cytometer (Becton Dickinson) at a flow rate of 250 cells/s. Dead cells and cell debris were excluded from acquisition by gating with FCS and SSC biparametric plot.

For the analysis of apoptosis, cells were resuspended in $1 \times$ Annexin $\mathrm{V}$ binding buffer, and stained with Cy5-Annexin V (BD Bioscience Pharmingen). Just before cell acquisition in a FACScalibur, $5 \mu$ l of 7-AAD was added.

Chromatin immunoprecipitation. Chromatin immunoprecipitation (ChIP) was performed using the ChIP Assay kit (Upstate). Briefly, $1-1.5 \times 10^{6}$ fixed cells were sonicated to shear the chromatin and immunoprecipitated using mouse anti-mouse BMI1 (US Biological), and anti-mouse $\operatorname{IgG}$ (Upstate) antibodies. Immunoprecipitated DNA was amplified using primers to $\mathrm{p} 21, \mathrm{HOXC} 13$, and $\beta$-major chain. Primers are p21 site 1; (F) 5' -AGCTTTCACCCCCAGAAACT- $3^{\prime}$ and (R) $5^{\prime}$ GATGATTTCTCCCAGGCTGA-3', p21 site 2; (F) 5'-TCAGCCTACAGCACCTGTCA-3' and (R) 5' -CAGCAAGGCAGACAGAACAG3', p21 site 3; (F) 5'-CTGTTCTGTCTGCCTTGCTG-3' and (R) 5'ATTGCCAGAGTCCAGCAGTT-3', p21 site 4; (F) 5' -ACACCCATGAGGGACACCT- $3^{\prime}$ and (R) $5^{\prime}$-ATACAAGGAAGGCCCTGGTC- $3^{\prime}$, p21 site 5; (F) 5'-ACCAGGGCCTTCCTTGTATC-3' and (R) 5'GTCACCCTCCAGTGGTGTCT-3', HOXC13 site 1; (F) 5'-ACGTGAACCTGCAGCAGAA-3' and (R) 5'-CTTGGCCCTAGAGGACAGGT-3', HOXC13 site 2; (F) 5' -AGCAGAGCTCAGTGGGAGAG-3' and (R) 5'-AATTTCAGGCCCACCCTTAG-3', $\beta$-major (F) $5^{\prime}$ GGCTGTCATCACTTAGACCTC-3' and (R) 5'-GGTTGCTAGTGAACACAGTTG-3'. $\beta$ major was used as an internal standard for data calibration, and the $2^{-\Delta \Delta \mathrm{Ct}}$ formula was used for the calculation of differential levels of immunoprecipitated chromatin.

Microarray analyses. Total RNA was prepared using TRIzol reagent (Invitrogen) and purified by the RNeasy MiniElute Cleanup kit (Qiagen) from scrambled-virus or shBMI1-infected GBM cells (two independent tumors were used, with three infections per virus). Microarray analysis using BeadChip Mouse Genome (Illumina) was performed at the Centre d'innovation at Genome Quebec (McGill University, Montreal, QC, Canada). Data were analyzed using the FlexArray software. Data were validated by real-time PCR for some transcripts.

Stereotactic intracranial cell transplantation into nonobese diabetic/severe combined immunodeficiency mice. Animals were handled in strict accordance with the Animal Care Committee of the Maisonneuve-Rosemont Hospital Research Centre. Cells were resuspended in oxygenated HBSS and $3 \mu \mathrm{l}$ aliquots were injected stereotactically into 60-d-old nonobese diabetic/severe combined immunodeficiency (NOD/SCID) mouse brain, after administration of general anesthesia (Somnotol; $60 \mathrm{mg} / \mathrm{kg}$ ). Mice were placed in the stereotactic frame using ear bars and a hole was bored in the skull. The injection coordinates were $2 \mathrm{~mm}$ to the right of the midline, $2 \mathrm{~mm}$ posterior to the coronal suture and $3 \mathrm{~mm}$ deep. The scalp was closed with wound clips (Harvard Apparatus). Animals were followed daily for development of neurological deficits.

Statistical analysis. Statistical differences were analyzed using Student's $t$ test for unpaired samples. An ANOVA followed by the Dunnett test was used for multiple comparisons with one control group. Survival curve statistics were made with the GraphPad Prism 5 software. The criterion for significance ( $p$ value) was set as mentioned in the figures.

\section{Results}

BMI1 and EZH2 are highly enriched in $\mathrm{CD} 133^{+}$GBM cells

We previously showed that in contrast with mouse astrocytes, normal human brain astrocytes do not express BMI1 in vivo (Chatoo et al., 2009). We sought to determine whether primary GBM tumors express BMI1 and EZH2. By using immunohistochemical stainings, we found that BMI1 and EZH2 are highly expressed in GBM tumors (five archival paraffin-embedded, and four newly resected tumors) (Fig. 1; data not shown). In these tumors, BMI1 was expressed in GFAP-positive cells, suggesting that BMI1 is expressed in transformed human astrocytes in vivo. EZH2 was highly expressed in Nestin-positive cells, which may correspond to astrocytes and/or neural stem cells (Fig. $1 \mathrm{~A}$; data not shown). Increasing reports had pointed that brain tumors originate from $\mathrm{CD}_{133}{ }^{+}$cancer stem-like cells that recapitulate the self-renewal and multilineage differentiation characteristics of the original tumor (Hemmati et al., 2003; Singh et al., 2003; Galli et al., 2004; Yuan et al., 2004). We found that BMI1 and EZH2 were coexpressed with CD133 in GBM tumors (Fig. $1 B$; data not shown). BMI1 and EZH2 expression in GBM tumors was accompanied by the expression of the progenitor/stem cell markers MUSASHI, SOX2 and LHX2 (Fig. 1C; supplemental Fig. $1 A$, available at www.jneurosci.org as supplemental material). It was also reported that cancer stem cells are frequently observed within vascular niches (Calabrese et al., 2007). BMI1 or EZH2expressing tumor cells were found intimately associated with CD31positive vessels (Vecchi et al., 1994) (Fig. 1D; data not shown).

Recent findings revealed that the gene expression profile of all GBM cell lines (such as the U87 cell line) does not reflect the expression profile of original GBM tumors (Lee et al., 2006). In contrast, GBM cell lines derived from GBM tumors but grown as neurospheres in serum-free neural stem cell (NSC) media share a much closer gene expression profile with the original tumors. Notably, GBM-derived neurospheres express BMI1 (Lee et al., 2006). We cultured cells isolated from six GBM tumors in NSC media. Five cell lines were established, generating neurospheres that could be maintained for $>15$ passages (Fig. $2 A$ ). When cultured in serum-containing media, these cells differentiated into neurons (MAP2- and NeuN-positive) and astrocytes (GFAPpositive) (Fig. $2 \mathrm{~A}$; data not shown). As previously reported, several differentiated cancer cells aberrantly coexpressed MAP2 and GFAP (Hemmati et al., 2003) (data not shown). Floating GBM neurospheres expressed BMI1 and EZH2 and the NSC markers MUSASHI, SOX2 and LHX2 as revealed by immunofluorescence, RT-PCR and Western blot analyses (Fig. 2A-C; data not shown). We sorted $\mathrm{CD}_{133^{-}}$and $\mathrm{CD} 133^{+}$cells from GBM neurospheres using magnetic microbeads. By using quantitative real time PCR, we found that BMI1 ( $~ 8$ times) and EZH2 ( $~ 3$ times) were highly enriched in the $\mathrm{CD}_{13}{ }^{+}$cell fraction (Fig. 2D). Moreover, by using flow cytometry analysis, we also found that BMI1 was expressed in $85 \%$ of $\mathrm{CD}_{133}{ }^{+}$cells (Fig. 2 E). These observations indicate that BMI1 is robustly expressed in GBM tumors and highly enriched in $\mathrm{CD}_{133}{ }^{+}$stem cell-like GBM cells.

\section{BMI1 is not amplified in GBM tumors}

PDGF and EGFR genes amplification as well as INK4A/ARF, PTEN and RB deletions, and P53 mutations are hallmarks of glioma transformation (Ohgaki and Kleihues, 2007; CGAR, 2008). Hence, high BMI1 expression level in GBM tumors may 

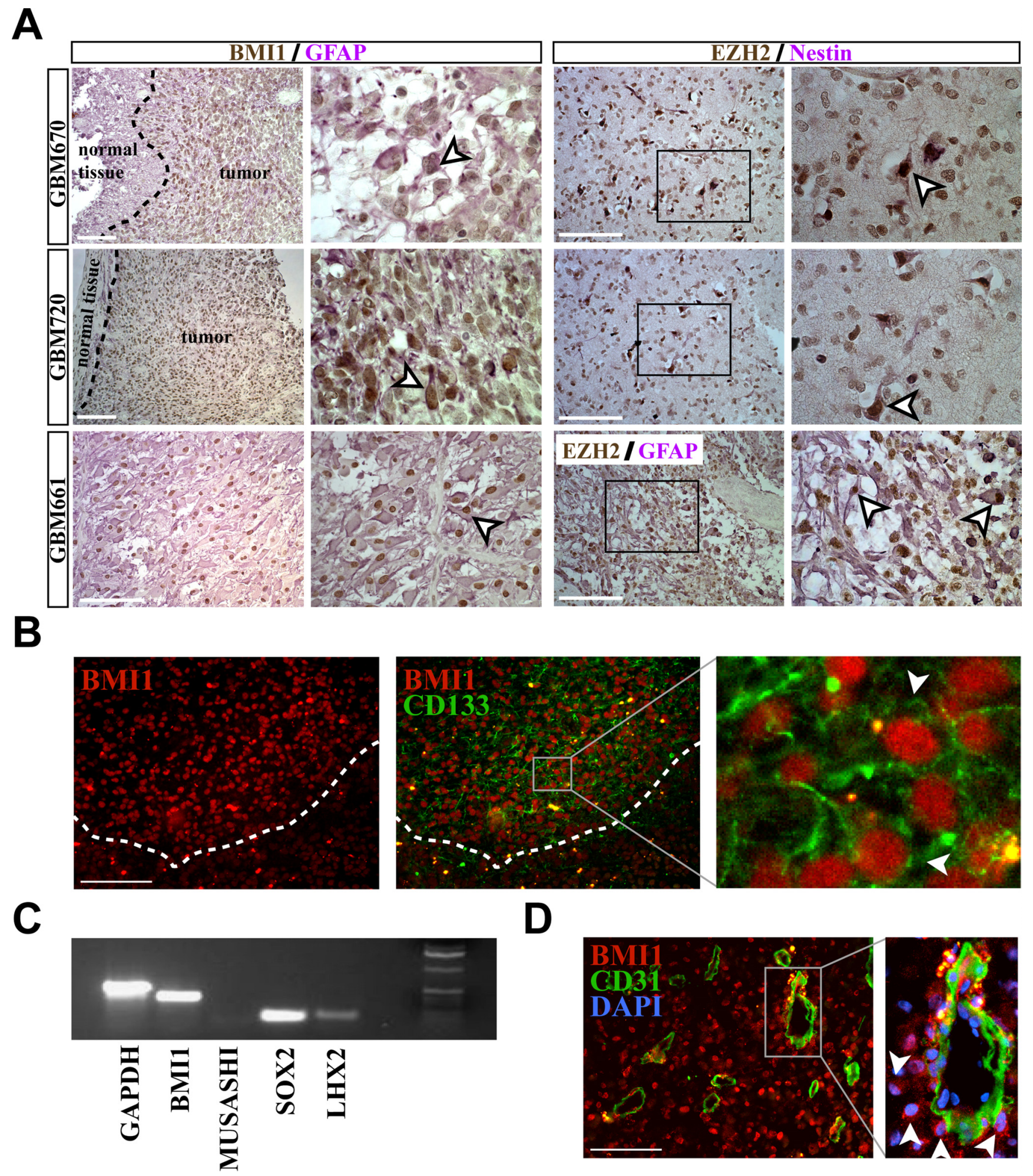

Figure 1. Glioblastoma multiforme tumors express BMI1 and EZH2.A, Formalin-fixed paraffin-embedded GBM samples were immunolabeled with antibodies against BMI1 or EZH2 (brown) and GFAP or Nestin (pink). Arrowheads point to double positive cells. B, Frozen GBM samples were immunolabeled with antibodies against BMI1 (red) and (D133 (green). DAPI (blue) stains nuclei. Arrowheads point to double positive cells. C, RT-PCR analysis performed on a freshly isolated GBM sample with primers against GAPDH, BMI1, MUSASHI, SOX2, and LHX2.D, Frozen GBM samples were immunolabeled with antibodies against BMI1 (red) and CD31 (green). DAPI (blue) stains nuclei. Arrowheads point to BMI1 cells surrounding a blood vessel. Dashed lines (in $\boldsymbol{A}$ and $\boldsymbol{B}$ ) delineate the border of the tumor. Scale bars, $100 \mu \mathrm{m}$.

also be caused by gene amplification. In most of our tumor samples, we observed EGFR and PDGFR amplifications as well as biallelic INK4A/ARF deletions (Fig. $2 F$ ). However, BMI1 gene amplification was not observed (Fig. $2 F$ ).
BMI1 knockdown inhibits colony growth and leads to $\mathrm{CD} 133^{+}$stem cell depletion

To address the role of BMI1 and EZH2 in GBM, we used replication-incompetent lentiviruses to knockdown these fac- 


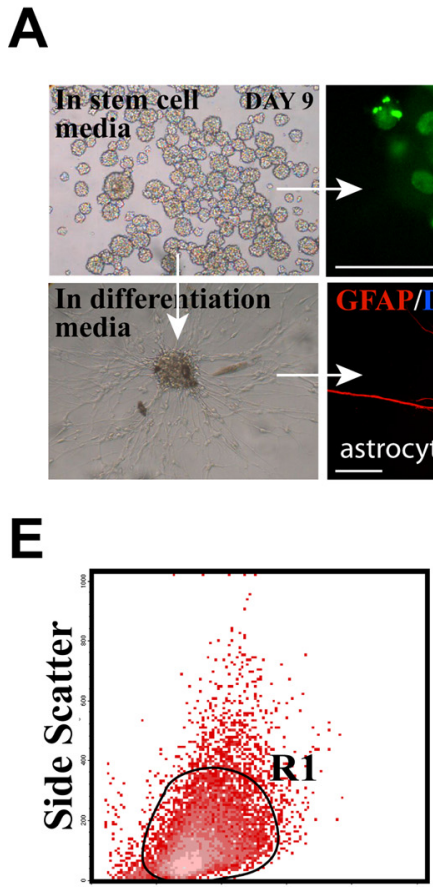

Forward Scatter

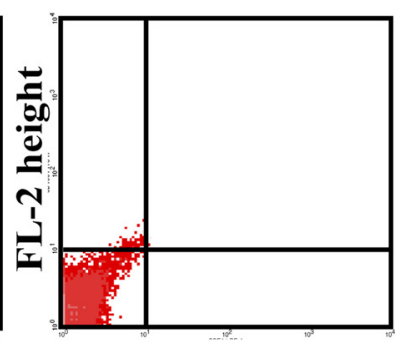

FL-1 height

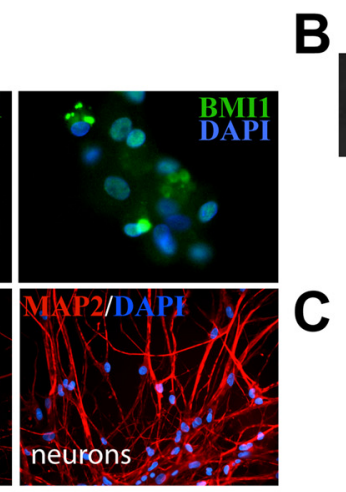

B
D

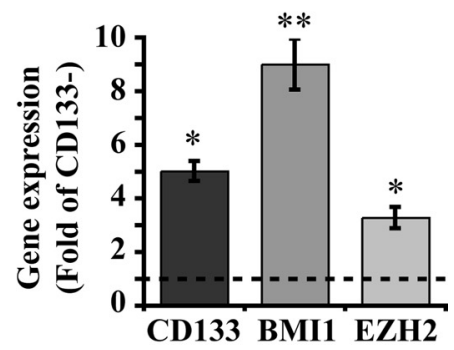
CD133 BMI1 EZH2

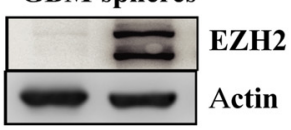

$\mathbf{F}$

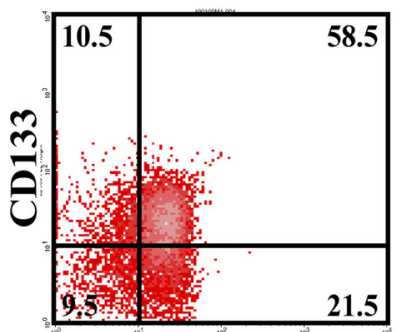

BMI1

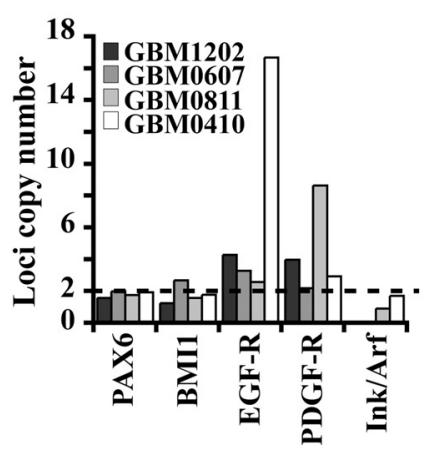

Figure 2. BMI1 and EZH2 are highly enriched in $\mathrm{CD} 133^{+}$cells. $A$, Frozen GBM neurospheres were immunolabeled with antibodies against BMI1 (top), or GFAP and MAP2 after plating in medium-induced differentiation (bottom). DAPI stains nuclei in blue. $B$, RT-PCR analysis performed on cultured neurospheres with primers against GAPDH, BMI1, MUSASHI, SOX2, and LHX2. C, Western blot analysis performed on freshly isolated GBM sample and neurospheres using anti-EZH2 and anti- $\beta$-actin antibodies. D, CD133 ${ }^{-}$and CD133 ${ }^{+}$purified GBM cells with CD133-coupled magnetic beads were analyzed by real-time PCR for the expression of PROMININ (CD133), BMI1, and EZH2 transcripts. Data are expressed as fold change over gene expression in negative cells $\left(C D 133^{-}\right)$, which was set at 1. Results are mean \pm SD $\left(n=3 ;{ }^{*} p<0.05 ;{ }^{* *} p<0.01\right)$. E, Dissociated neurospheres were stained with anti-BMI1 and anti-CD133 antibodies. The R1 gate delineates the cell population analyzed. Values are the percentages of cells in the corresponding regions. $\boldsymbol{F}$, Gene copy number was assessed by quantitative real-time PCR in GBM samples. Data are expressed relative to healthy human retina genomic DNA and calibrated to $\beta$-actin used as internal standard. Another internal standard was used which consisted of PAX6. Scale bars, $60 \mu \mathrm{m}$.

tors. A lentiviral construct driving an shRNA under the control of the U6 promoter and a fusion hygromycin/GFP protein under the control of the CMV promoter was used (Ivanova et al., 2006). BMI1 or EZH2 expression was significantly reduced in 293T cells and in cultured GBM cells using different shRNA constructs (Fig. $3 A$; supplemental Fig. $1 B$, available at www.jneurosci.org as supplemental material).

These viruses were used to infect 3 independent GBM cell lines cultured on Matrigel in NSC media, where a total of 5000 cells ( 2500 cells $/ \mathrm{ml}$ ) were plated per well. In this colony-forming assay, control-virus-infected GBM cells generated adherent colonies growing as a dense cell monolayer (Fig. $3 B$ ). In contrast, knockdown of BMI1 or EZH2 resulted in fewer colonies growing as a loose cell monolayer (Fig. 3B; supplemental Fig. 2, available at www.jneurosci.org as supplemental material).

We also used the classical neurosphere assay to evaluate the effect of BMI1 knockdown. Virus-infected cells (with $>95 \%$ of infection as visualized by GFP fluorescence) were grown in NSC media with hygromycin in nonadherent cell culture dishes at 2000 cells/ml. After 5 d, we observed that BMI1 knockdown resulted in smaller sphere colonies, and this effect was apparently dose-dependent (Fig. 3C). After 2 weeks, control colonies generated a dense neuroepithelial cell layer reaching near confluence. In contrast, shBMI1\#1-infected cells did not reach confluence and had a differentiated morphology. When cells were serially cultured, we observed that shBMI1\#1-infected cells were unable to ensure continues passages, and were depleted after the first passage (Fig. 3D). ShBMI\#3-infected cells could grow for serial passages but more slowly than the control cell population (Fig. 3D).

Cell growth retardation may result from increased apoptosis or differentiation, and/or reduced proliferation. When compared with control GBM cells, shBMI1-infected cells displayed significantly more apoptosis at 24,48 and $72 \mathrm{~h}$ postinfection $(\sim 4-7$ times) (Fig. 3E; data not shown). When neurospheres grown in NSC media were plated on a gelatin matrix to force adhesion, we observed after $48 \mathrm{~h}$ that shBMI-infected colonies contained more neurons $\left(\mathrm{MAP}^{+}\right)$and astrocytes $\left(\mathrm{GFAP}^{+}\right)$than the control culture (Fig. 3F). To better understand cell fate after BMI1 knockdown, we analyzed stem cell genes expression (CD133/ PROMININ, MUSASHI, SOX2 and LHX2). In colonies grown for 2 weeks in NSC media (as in panel 3C), BMI1 knockdown was accompanied by a dramatic reduction in stem cell genes expression, thus suggesting depletion of the stem cell pool (Fig. $3 G$ ). Notably, even partial BMI1 knockdown with shBMI1\#3 (44\% of remaining transcripts) significantly affected CD133/PROMININ expression (Fig. 3G). These observations reveal that BMI1 is required to prevent apoptosis and/or differentiation of the $\mathrm{CD}_{133^{+}}$stem cell population.

\section{Cell density modulates $\mathrm{CD}_{133^{+}}$cell survival}

BMI1 knockdown leads to apoptosis and depletion of the $\mathrm{CD}_{133^{+}}$cell population in low-density cell culture conditions. We hypothesized that cell density may be important for cell via- 
A
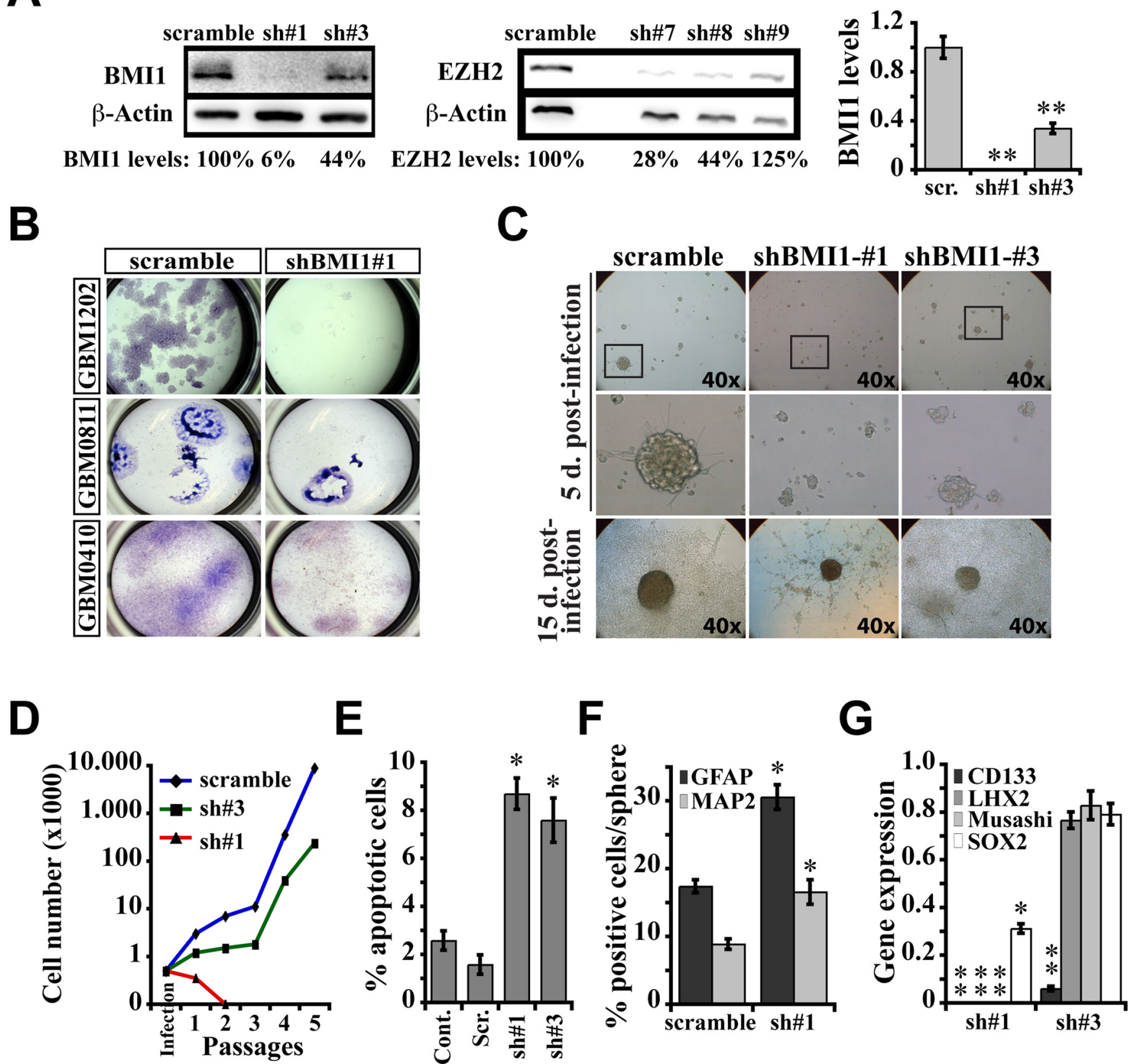

Figure 3. BMI1 or EZH2 knockdown reduces GBM cells clonogenic potential and leads to depletion of the CD133 ${ }^{+}$cell population. $\boldsymbol{A}$, shRNA downregulation of BMI1 and EZH2 expression. Western blot analysis performed on shBMI1- or scramble-infected 293FT cells using anti-BMI1, anti-EZH2, and anti- $\beta$-actin antibodies. $\beta$-Actin was used as an internal standard to quantify BMI1 and EZH2 expression levels (left and middle). GBM cells were infected with one of two lentiviruses expressing shBMI1, or scramble virus, and were analyzed by real-time PCR for the expression of BMI1 transcripts. Data are expressed as fold change over BMI1 expression in the scramble-infected cells, which was set at 1. Results are mean \pm SD $\left(n=3 ;{ }^{* *} p<0.01\right)$ (right). $\boldsymbol{B}$, ShBMI1 or scramble-infected GBM cells were plated on Matrigel substrate. Forty-eight hours later, hygromycin selection was added and cells were allowed to grow for $10 \mathrm{~d}$. Cultures were fixed and stained with cresyl violet, and phase contrast micrographs were taken. C, ShBMI1 or scramble-infected GBM cells were plated on non-adherent culture plates. Forty-eight hours later, hygromycin selection was added and cells were allowed to grow for 2 weeks. $\boldsymbol{D}$, Cells cultured in $\mathbf{C}$ were followed for 5 passages. Colonies were passaged every 2 weeks. Results are cumulative cells number (log scale) over consecutive passages. Note that shBMI1-\#1-infected cells were depleted after the first passage. E, GBM cells cultured as in C were analyzed for apoptosis using Annexin-V staining and FACS analysis. Data are expressed as the percentage of Annexin $+/ 7-A A D-$ cells (mean $\pm S D ; n=3 ;{ }^{*} p<0.05$ ). $F$, ShBMI1 or scramble-infected GBM cells were plated on gelatin-coated chamber slides and allowed to differentiate for $7 \mathrm{~d}$. Cultures were analyzed by immunofluorescence using antibodies against GFAP, or MAP2. Data are expressed as the percentages of positive cells over the total number of DAPI-stained nuclei $\left(n=3 ;{ }^{*} p<0.05\right)$. G, GBM cells cultured as in C were analyzed by real-time PCR. Data are expressed as fold change over gene expression in the scramble-infected cells, which was set at 1 . Results are mean $\pm \mathrm{SD}\left(n=3 ;{ }^{*} p<0.05 ;{ }^{* *} p<0.01\right)$.

bility. We cultured scramble- and shBMI1-infected GBM cells at $2.5 \times 10^{4}$ cells $/ \mathrm{ml}$ in NSC media for $5 \mathrm{~d}$ in the presence of hygromycin. Under these conditions, we found that the overall proportion of $\mathrm{CD} 133^{+}$was comparable in both cell populations (Fig. $4 A, B)$. Cell sorting analysis revealed that only $\mathrm{CD} 133^{+}$cells could form colonies, and that shBMI1-infected $\mathrm{CD} 133^{+}$cells generated smaller colonies then scramble-infected cells (Fig. 4C). We also analyzed cells by fluorescence-activated cell sorting (FACS) for Annexin-V staining and observed that culturing shBMI1-infected cells at high density reduced apoptosis at levels 
A

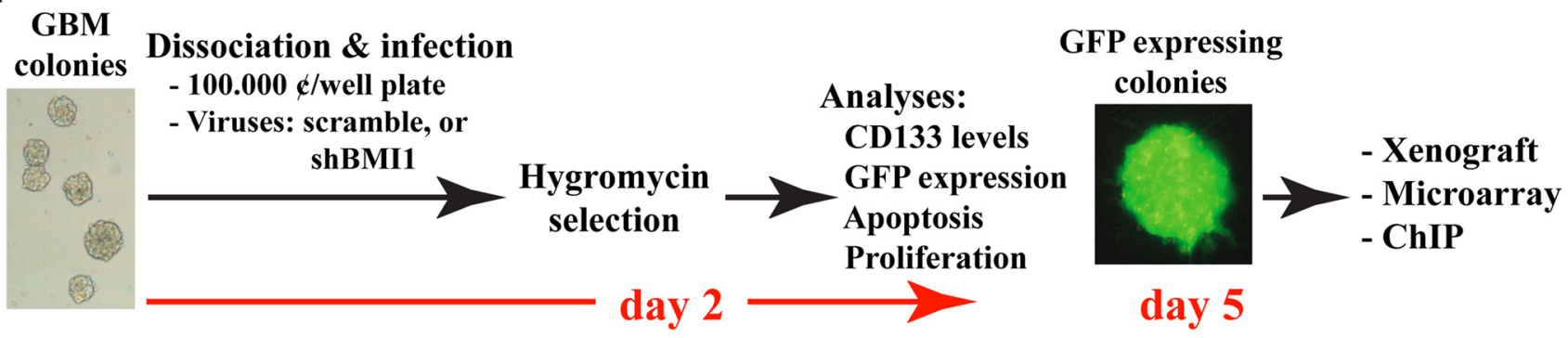

B
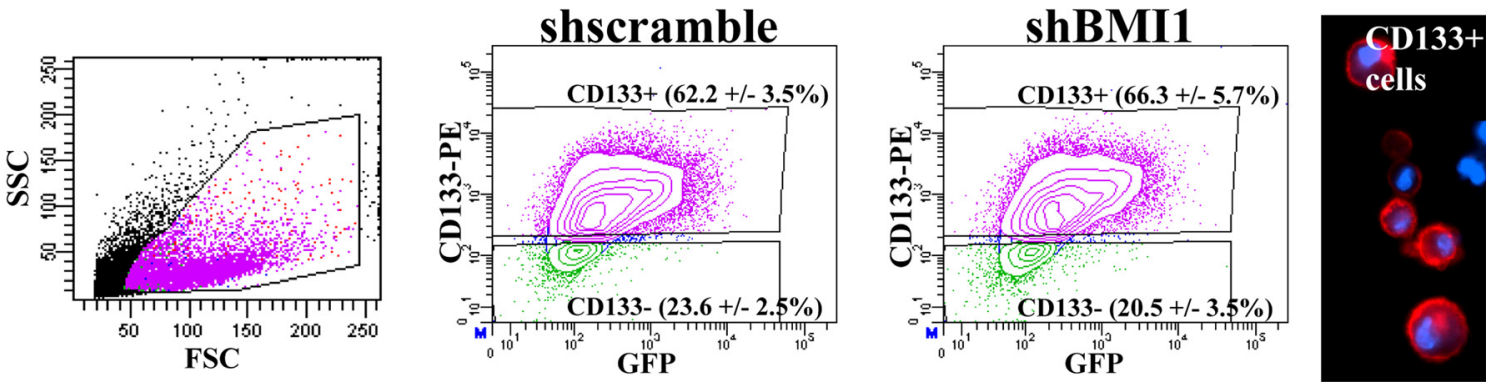

C
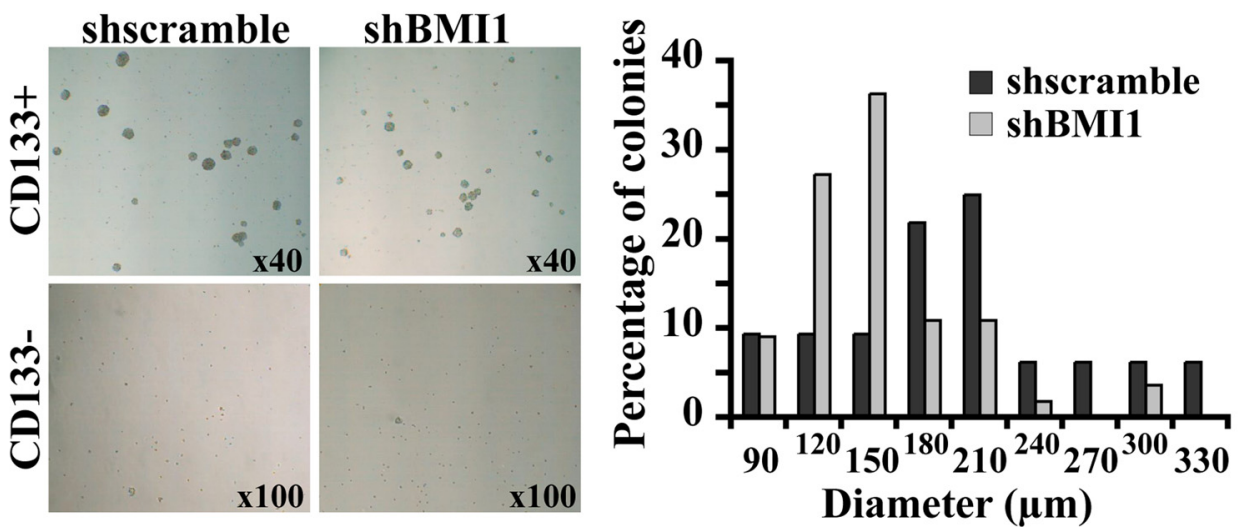

Figure 4. High cell density prevents CD133 ${ }^{+}$cell depletion after BMI1 knockdown. $\boldsymbol{A}$, Experimental scheme used to study differential gene expression (Microarray), BMI1 binding to candidate genes (ChIP), and BMI1 function in vivo. B, Scramble or BMI1 shRNA-infected neurospheres were dissociated and stained with anti-CD133 antibodies. The R1 gate delineates the cell population analyzed. All cells analyzed were GFP positive. The values are the percentages of CD133 ${ }^{+}$and CD133 ${ }^{-}$in both cultures. The panel to the right shows CD133 ${ }^{+}$and CD133 ${ }^{-}$cells as viewed under a fluorescence microscope. C, Size distribution of spheres obtained from scramble or shBMI1-infected CD133 ${ }^{+}$or CD133 ${ }^{-}$sorted cells after $5 \mathrm{~d}$ of culture. Phase contrast pictures are shown.

that were comparable to controls $(4.3 \pm 0.7$ in scramble-infected cultures versus $5.0 \pm 0.6$ in shBMI1-infected cultures; $n=5$ independent cultures). These culture conditions, which at least transiently preserve the $\mathrm{CD} 133^{+}$cell population, allowed us to further study the biological and molecular functions of BMI1 in gliomagenesis.

BMI1 is required for brain tumor formation in xenografts To investigate the role of BMI1 in tumor growth in vivo, $1 \times 10^{5}$ GBM cells infected with either controls or shBMI1 viruses were injected stereotactically in brains of NOD/SCID mice. We analyzed the expression of CD133 by FACS in cells cultured at high density $\left(2.5 \times 10^{4}\right.$ cells $\left./ \mathrm{ml}\right)$. At the time of injection and depending on the cell line, $20-65 \%$ of both control- and shBMI1-virusinfected cells expressed CD133. After 6-8 weeks, all control group animals (i.e., GFP virus, $n=15$; scramble virus, $n=14$; or no virus, $n=15$ ) started to show neurological symptoms or die suddenly. In contrast, most animals injected with the shBMIGBM cells survived $(n=21)$. Kaplan-Meyer survival curve showed that mice injected with control cell (i.e., naive cells)- or empty virus (i.e., GFP)-infected, or scrambled virus-infected cells (i.e., scramble) died prematurely when compared with naive NOD/SCID mice (Christianson et al., 1997) or with mice injected with shBMI1-infected cells (Fig. 5A, B). Mice bearing xenografts in which BMI1 was knockdown exhibited a median survival that was very close to that of normal NOD/SCID mice (Fig. 5A, B) (Christianson et al., 1997). In control animals, typical hemorrhagic GBM tumors $(n=11)$ were observed macroscopically (Fig. 5C), and could be used to establish new glioma neurosphere cultures when dissociated and maintained in NSC media (data not show). We also observed large invasive but nonhemorrhagic tumors crossing both brain hemispheres $(n=3)$. One very large tumor (but noninfiltrating) that was histologically similar to the tumor of origin was obtained (supplemental Fig. 3, available at www.jneurosci.org as supplemental material). In contrast, no tumors were found in the brain of mice injected with shBMI1infected cells (macroscopically or microscopically). In one animal that was killed at day 32 post-transplantation for the presence 
of a thymic tumor, we could detect transplanted human GBM cells lining the cortical ventricular zone, nearby the hippocampus (Fig. 5D). However, these cells did not form a tumor mass.

Histological analysis of solid hemorrhagic tumors in control animals revealed expression of the GFP transgene and of the human-specific mitochondrial antigen, confirming the human origin of the tumor (Fig. 6B, C). BMI1, EZH2, Ki67, PCNA, Nestin and GFAP were robustly expressed in these tumors (Fig. 6A-D). Altogether, these observations show that cultured GBM cells retain the capacity to generate brain tumors resembling the tumor of origin and expressing BMI1 and $\mathrm{EZH} 2$.

To investigate why shBMI1-infected glioma cells did not generate tumors, we transplanted $1 \times 10^{5}$ cells infected with shBMI1 or scrambled viruses. Animals were analyzed $10 \mathrm{~d}$ postinjection. In control animals, we observed a tumor mass within the right ventricle (Fig. 7A). A similar but smaller mass was observed in animals injected with shBMI1-infected GBM cells (Fig. 7A). Both cell masses expressed the GFP transgene, indicating their human origin (Fig. $7 B$ ). We also noticed that grafted cells were sometime in very close association with the microvasculature of the cortical ventricular zone (Fig. $7 B$ ). Whereas a small fraction of control tumor cells were positive for activated caspase-3, nearly all shBMI1-infected tumor cells were positive, revealing massive apoptosis (Fig. 7B). Thus, although high cell density can transiently preserve cell viability of shBMI1-infected glioma cells in vitro, this is not sufficient to prevent cell death after transplantation in mice. These results revealed that BMI1 is required for GBM tumor development in vivo.

\section{BMI1 regulates multiple \\ cellular pathways}

To identify the molecular pathways underlying the observed effects of BMI1 knockdown, we surveyed gene expression changes by performing DNA micro-array analyses. Since BMI1 main function is attributed to its repressive action on the INK4A/ARF locus (Jacobs et al., 1999a), we used two INK4A/ARF-deleted tumor cell lines (GBM1202 and GBM0607) (Fig. $2 F$ ) to identify alternate pathways that may required active transcriptional repression by BMI1 to allow for gliomagenesis. We found significant changes in the expression (either up or down) of 1769 genes in the shBMI1-infected cells compared with either control shRNA or non-
A

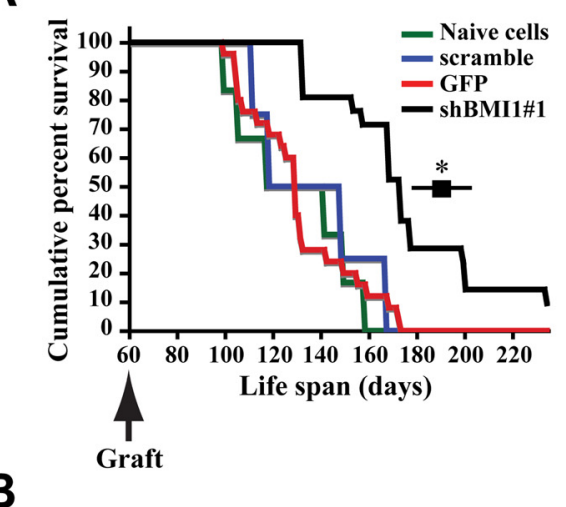

\begin{tabular}{|r|c|c|c|c|}
\cline { 2 - 5 } \multicolumn{1}{c|}{} & Control & scramble & GFP & shBMI1\#1 \\
\hline \# of mice & 15 & 14 & 15 & 21 \\
\hline Median & 130 & 134 & 138 & 179 \\
survival & & & 0.32 & 2.94 \\
Chi square & 0.46 & & 0.57 & 0.03 \\
P value & 0.49 & & \\
\hline
\end{tabular}

C

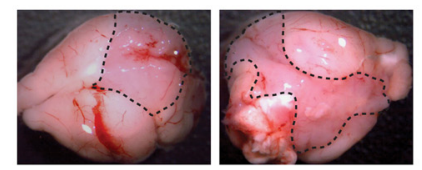

D
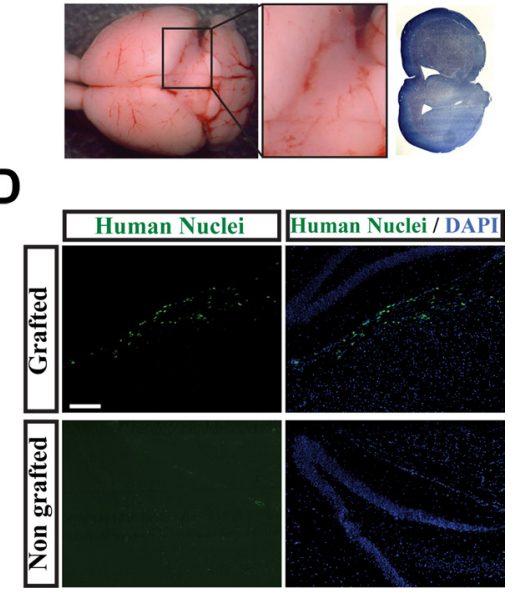

Figure 5. BMI1 is required for intracranial GBM tumor formation. $\boldsymbol{A}$, Kaplan-Meyer representation of the survival curves of mice injected with naive cells, cells infected with an empty virus, a scrambled or a ShBMl1 viruses. *Median survival for this mouse strain was previously reported (mean \pm SD; $191 \pm 11$ d) (Christianson et al., 1997). B, Data summary from the Kaplan-Meyer curves shown in $\boldsymbol{A}$. Statistical significance was assessed using the log rank test relative to scramble. $\boldsymbol{C}$, Representative images of brains bearing secondary tumors following engraftment of scrambled virus-infected GBM cells. Tops Hemorrhagic tumor (dashed lines). Bottom, Nonhemorrhagic tumor. Cresyl violet coloration showed that GBM cells localize mainly in the grafted right hemisphere with some spreading in the contralateral hemisphere. $D$, Frozen sections of a brain injected with shBMI1-infected GBM cells were immunolabeled with antibodies to human nuclei (green). Nuclei were visualized by DAPI (blue). The grafted cells were confined to the injection site. The contralateral left hemisphere was used as a nongrafted control. Scale bar, $200 \mu \mathrm{m}$.

A
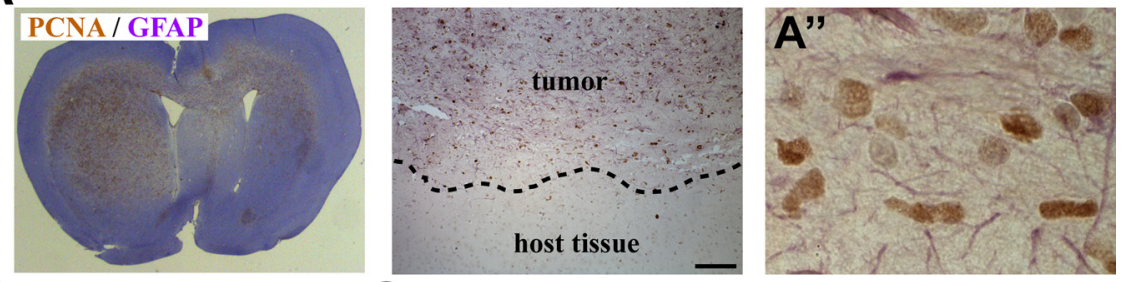

B

C
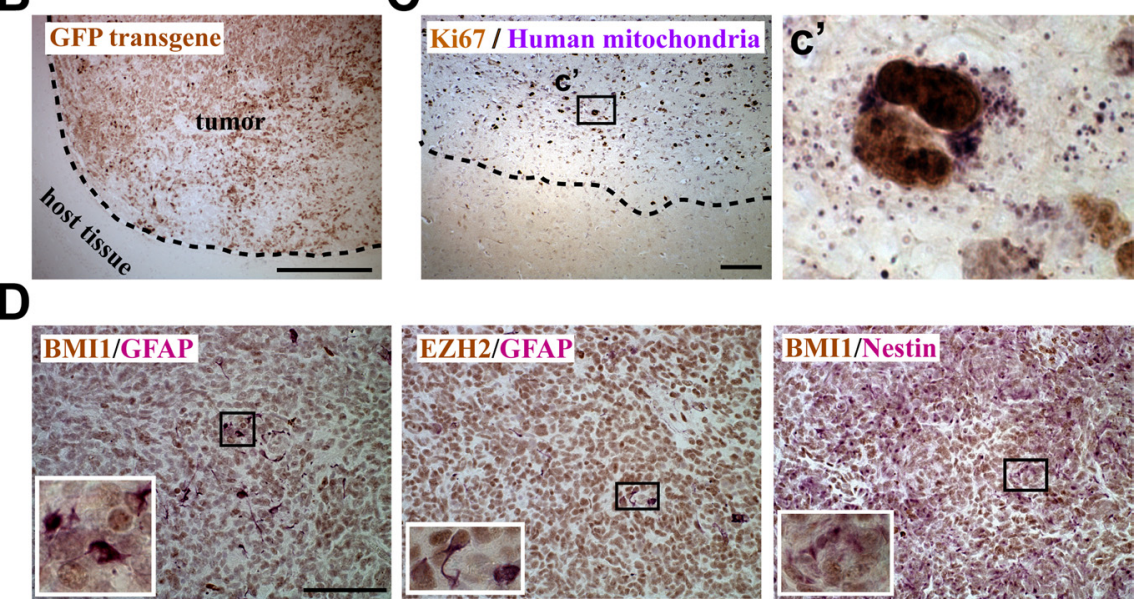

Figure 6. Engrafted tumors resemble the tumor of origin and retain PcG proteins expression. Formalin-fixed paraffinembedded sections of brains injected with scrambled virus-infected GBM cells were analyzed by immunohistochemistry. $A$, Sections were immunolabeled with antibodies against PCNA and GFAP. $\boldsymbol{B}$, Sections were immunolabeled with antibodies against GFP (from the lentiviral transgene). C, Sections were immunolabeled with antibodies against human mitochondria and Ki67. D, Sections were immunolabeled with antibodies against BMI1, EZH2, GFAP, and Nestin. Dashed line delineates the border of the tumor. Scale bar, $100 \mu \mathrm{m}$. 
A
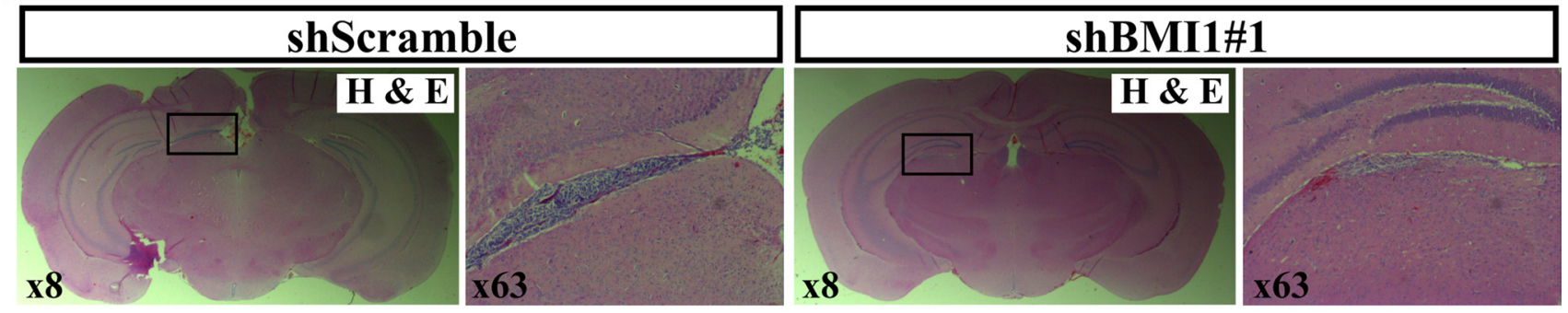

B
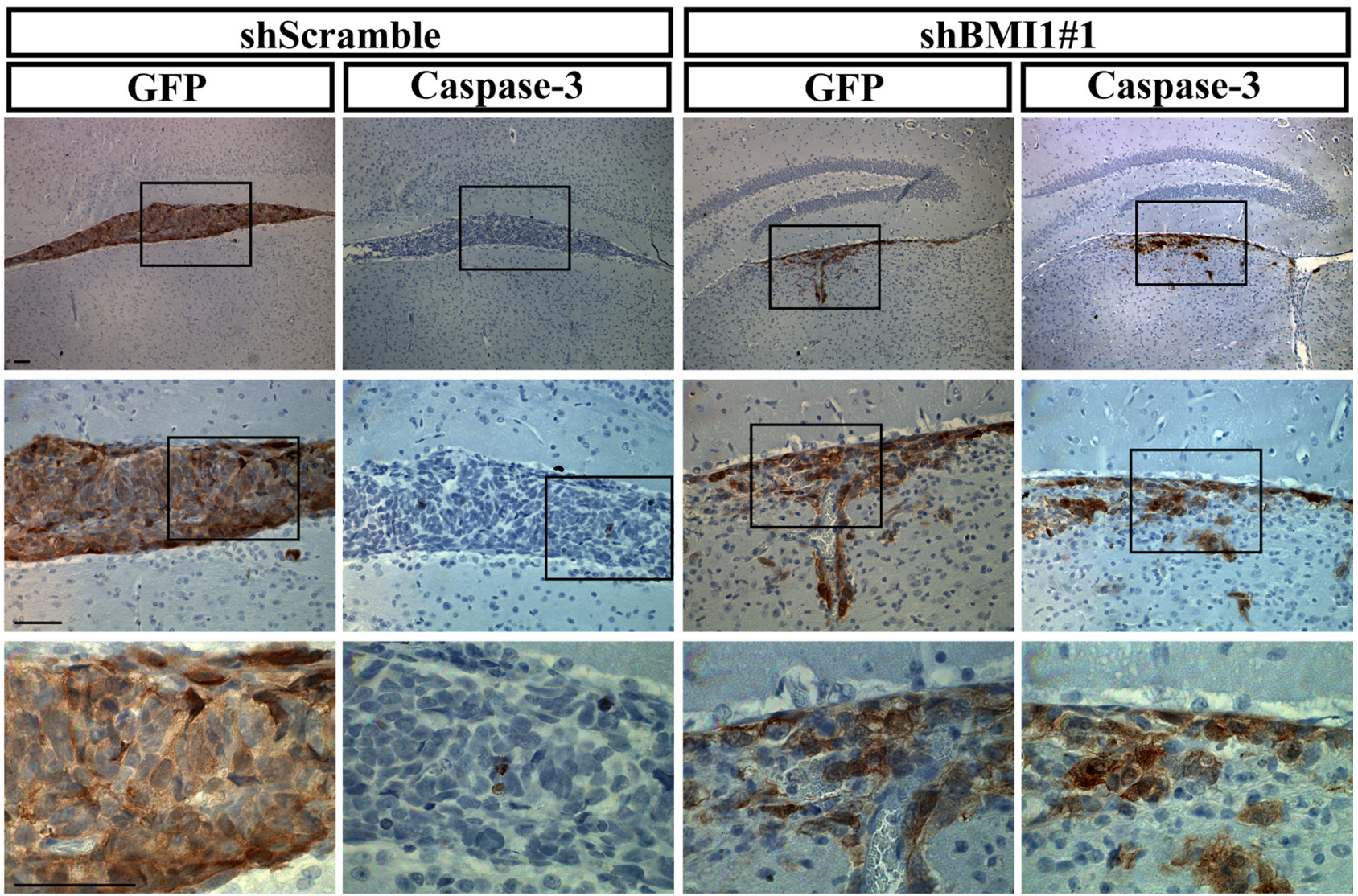

Figure 7. BMI1 knockdown results in glioma cell apoptosis in vivo. $\boldsymbol{A}, \boldsymbol{B}$, Formalin-fixed paraffin-embedded sections of brains injected with scrambled- or shBMI1-infected GBM cells were analyzed by immunohistochemistry $10 \mathrm{~d}$ postinjection. $\boldsymbol{A}$, Sections were stained with hematoxylin and eosin. The tumor cell mass was consistently found in the right ventricle. $\boldsymbol{B}$, Sections were immunolabeled with antibodies against GFP (carried by the transgene), or cleavage-activated caspase-3. GFP immunoreactivity revealed that tumor cells are in close association with the microvasculature. Caspase-3 immunoreactivity uncovered that BMI1 knockdown cells undergo massive apoptosis. Scale bars, $50 \mu \mathrm{m}$.

infected cells. Both cell lines gave nearly identical differential gene expression profiles. No relevant differences in gene expression were detected between noninfected and control shRNAexpressing cells (data not shown).

Because BMI1 is a transcriptional repressor (Lee et al., 2006; Chatoo et al., 2009), we first focused on upregulated genes. More than 12 homeobox genes of the HOX gene cluster, which are known direct BMI1 targets, were differentially expressed (Alkema et al., 1995; van der Lugt et al., 1996; Hanson et al., 1999; Molofsky et al., 2003). This confirmed the validity of our assay (Table 1; supplemental Table, available at www.jneurosci.org as supplemental material). Notable observations were the massive upregulation of antigen presentation (HLA) molecules, Notch ligands and downstream targets, neural and glial differentiation markers, as well as cell cyclecontrol, cell death and stress response factors, i.e., P21 ${ }^{\text {Cip }}$,
P18 ${ }^{I N K 4 C}$, FOXOA3, GAS1 and GADD45 (Table 1; supplemental Table, available at www.jneurosci.org as supplemental material). We also identified 2 genes known as markers of progenitor/stem cells that were downregulated in shBMI1-infected cells (CD133/ PROMININ and NUMB) as well as one cell proliferation marker (PCNA). These results strengthened the idea that BMI1 maintain cancer stem cells in an undifferentiated state and that abrogation of its activity results in the induction of cell death, cell cycle exit and/or differentiation pathways (Table 1; supplemental Table, available at www.jneurosci.org as supplemental material). Based on genetic studies, Bmil was proposed to control $p 21^{\text {Cip } 1}$ expression in murine embryonic cortical progenitors (Fasano et al., 2007). ChIP experiments using GBM cells revealed that BMI1 could directly bind the chromatin at the $P 21^{C i p}$ promoter and $H O X C 13$ promoter (positive control), but not at the $\beta$-MAJOR promoter of the $\beta$-GLOBIN gene (negative control) (Fig. $8 A, B$ ). This provides the 
Table 1. BMI1 knockdown induces an upregulation of critical cell death, growth arrest, and cell differentiation pathways

\begin{tabular}{|c|c|c|c|c|c|}
\hline Target ID & Definition & Array & $p$ value & qPCR & $p$ value \\
\hline \multicolumn{6}{|l|}{ HLA cluster } \\
\hline HLA-DRB4 & Major histocompatibility complex, class II, DR $\beta 4$ & 4.291 & $6.3 \times 10^{-5}$ & 1.945 & 0.0001 \\
\hline HLA-DPA1 & Major histocompatibility complex, class II, DP $\alpha 1$ & 3.186 & $7.6 \times 10^{-5}$ & 3.575 & 0.0080 \\
\hline HLA-DRA & Major histocompatibility complex, class II, DR $\alpha$ & 2.659 & $2.7 \times 10^{-4}$ & 4.53 & 0.0368 \\
\hline HLA-DMA & Major histocompatibility complex, class II, DM $\alpha$ & 2.281 & $6.6 \times 10^{-5}$ & 2.885 & 0.0134 \\
\hline HLA-DMB & Major histocompatibility complex, class II, DM $\beta$ & 2.119 & $3.3 \times 10^{-5}$ & n.d. & \\
\hline \multicolumn{6}{|l|}{ HOX cluster } \\
\hline H0XB5 & Homeo box B5 & 2.331 & $3.4 \times 10^{-4}$ & n.d. & \\
\hline HOXB2 & Homeo box B2 & 2.134 & $3.33 \times 10^{-4}$ & n.d. & \\
\hline HOXA9 & Homeo box A9 & 1.962 & $2.46 \times 10^{-4}$ & n.d. & \\
\hline H0XB7 & Homeo box B7 & 1.715 & $2.10 \times 10^{-3}$ & n.d. & \\
\hline HOXB8 & Homeo box B8 & 1.621 & $3.02 \times 10^{-4}$ & n.d. & \\
\hline \multicolumn{6}{|c|}{ Notch signaling pathway } \\
\hline DLL1 & Delta-like 1 (Drosophila) & 2.507 & $7.1 \times 10^{-5}$ & n.d. & \\
\hline LFNG & Lunatic fringe homolog (Drosophila) & 2.428 & $1.8 \times 10^{-5}$ & n.d. & \\
\hline HEY1 & Hairy/enhancer-of-split related with YRPW motif 1 & 2.274 & $1.1 \times 10^{-7}$ & n.d. & \\
\hline DLK1 & Delta-like 1 homolog (Drosophila) & 2.232 & $6.7 \times 10^{-5}$ & n.d. & \\
\hline DLL3 & Delta-like 3 (Drosophila) & 2.228 & $1.4 \times 10^{-4}$ & n.d. & \\
\hline \multicolumn{6}{|c|}{ Cell death and growth } \\
\hline GADD45G & Growth arrest and DNA-damage-inducible $\gamma$ & 2.386 & $5.1 \times 10^{-6}$ & n.d. & \\
\hline EMP1 & Epithelial membrane protein 1 & 2.226 & $4.5 \times 10^{-5}$ & n.d. & \\
\hline NALP1 & NACHT, leucine rich repeat and PYD containing 1 & 2.078 & $2.2 \times 10^{-5}$ & n.d. & \\
\hline GAS1 & Growth arrest-specific 1 & 2.061 & $3.4 \times 10^{-4}$ & n.d. & \\
\hline F0X03A & Forkhead box 03A & 1.592 & $6.88 \times 10^{-6}$ & 2.865 & 0.029 \\
\hline CDKN1A & Cyclin-dependent kinase inhibitor 1A (p21, Cip1) & 1.349 & $2.6 \times 10^{-5}$ & 3.555 & 0.0315 \\
\hline CDKN2C & Cyclin-dependent kinase inhibitor 2 C (p18) & 1.320 & $8.6 \times 10^{-4}$ & 6.840 & 0.0125 \\
\hline \multicolumn{6}{|c|}{ Neuronal development and differentiation } \\
\hline GABBR2 & $\mathrm{GABA}_{\mathrm{B}}$ receptor 2 & 6.352 & $2.2 \times 10^{-5}$ & n.d. & \\
\hline NXPH1 & Neurexophilin 1 & 3.031 & $1.2 \times 10^{-4}$ & n.d. & \\
\hline EPHA4 & EPH receptor A4 & 2.259 & $9.5 \times 10^{-8}$ & n.d. & \\
\hline ENC1 & Ectodermal-neural cortex (with BTB-like domain) & 2.181 & $5.0 \times 10^{-4}$ & n.d. & \\
\hline FHL1 & Four and a half LIM domains 1 & 2.168 & $1.4 \times 10^{-4}$ & n.d. & \\
\hline \multicolumn{6}{|c|}{ Astrocyte phenotype } \\
\hline FGFR3 & Fibroblast growth factor receptor 3 & 2.419 & $5.6 \times 10^{-5}$ & n.d. & \\
\hline GFAP & Glial fibrillary acidic protein & 2.006 & $5.90 \times 10^{-7}$ & n.d. & \\
\hline \multicolumn{6}{|c|}{ Oligodendrocyte phenotype } \\
\hline OMG & Oligodendrocyte myelin glycoprotein & 2.042 & $2.1 \times 10^{-8}$ & n.d. & \\
\hline PDGFRA & Platelet-derived growth factor receptor $\alpha$ & 2.017 & $9.2 \times 10^{-5}$ & n.d. & \\
\hline \multicolumn{6}{|c|}{ Stem cell phenotype } \\
\hline NUMBL & Numb homolog (Drosophila)-like & $0.707^{a}$ & $1.3 \times 10^{-6}$ & n.d. & \\
\hline CD133 & Prominin 1 (PROM1) & $\overline{0.687}$ & $5.7 \times 10^{-7}$ & 0.01 & 0.0001 \\
\hline BMI1 & Polycomb group ring finger 4 (PCGF4) & 0.325 & $6.0 \times 10^{-14}$ & 0.01 & 0.0002 \\
\hline
\end{tabular}

GBM cells (from two independent tumors) were infected or not infected with scrambled virus or shBMI1\#1. Cells were maintained in culture at high density $\left(2.5 \times 10^{4}\right.$ cells $\left./ \mathrm{ml}\right)$ in neural stem cell media. No relevant differences in gene expression were detected between noninfected and scrambled shRNA-expressing cells. Data were analyzed using the FlexArray software and were expressed as fold change (Array column) over values in scrambled shRNA-infected cells. Data were validated by real-time PCR (qPCR column) for some transcripts. n.d., Not determined.

${ }^{a}$ Values with underlines are for genes whose expression was downregulated.

first molecular evidence that the regulation of $P 21^{\text {Cip }}$ by BMI1 is direct.

\section{Discussion}

BMI1 has been involved in the pathogenesis of several human malignancies (Lessard and Sauvageau, 2003; Bruggeman et al., 2007). Overexpression of BMI1 was found in medulloblastoma, lung and breast tumors (Vonlanthen et al., 2001; Kim et al., 2004; Leung et al., 2004). Abnormal EZH2 expression is also associated with human cancers (Kleer et al., 2003). We report here that BMI1 and EZH2 are expressed in GBM tumors, highly enriched in $\mathrm{CD}_{133^{+}}$tumor-initiating cells, and required for tumor cell growth.

\section{What is the mechanism of BMI1 upregulation in GBM tumors?}

BMI1 gene amplification has been identified in human B-cell lymphoma lines (Beà et al., 2001). However, we did not detect BMI1 gene amplification in four independent GBM tumors. This suggests that high BMI1 expression level in GBM cells is caused by increased gene transcription. BMI1 expression levels may simply reflect the stem cell state of GBM tumors, since BMI1 is highly expressed in normal neural stem cells (Molofsky et al., 2003; Zencak et al., 2005). Alternatively, "supraphysiological" BMI1 levels in cancerous neural stem cells may be required to confer biological properties that are not present in normal cells. This 
A

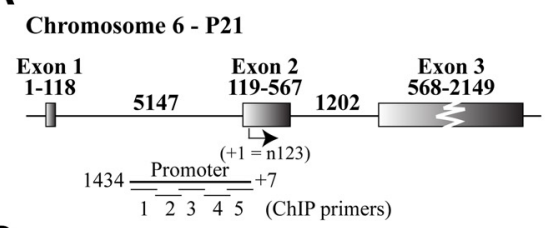

B

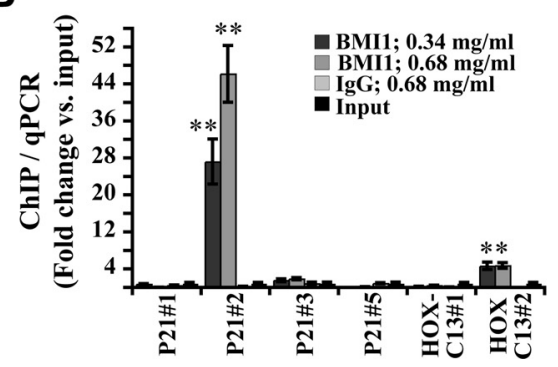

Figure 8. BMI1 promotes GBM tumor formation and stem cell renewal by blocking alternate tumor suppressor pathways. $A_{\text {, }}$ Schematic representation of the genomic DNA sequence of $\mathrm{P} 21^{\mathrm{Cip} 1}$. The boxes represent the exons. The primers used were chosen in the promoter region. $\boldsymbol{B}$, ChlP was performed with cultured GBM cell extracts. Immunoprecipitated DNA/protein complexes were analyzed by real-time $P C R$ using primers directed against the $P 21$ ( 5 sites), HOXC13 (2 sites), and $\beta$-MAJOR promoters. Data are expressed as fold change relative to the input, which was set at 1 . Results are mean $\pm S D\left(n=5 ;{ }^{*} p<0.05 ;{ }^{* *} p<0.01\right)$. $C$, Model of BMI1 function in gliomas. Crossed lines highlight the most common mutations and deletions found in GBM (CGAR, 2008). Dashed lines represent the classical targets of BMI1. Red lines represent possible new BMI1 targets, as reported in this study. Based on this finding, we propose that GBM tumor dependency over BMI1 is mediated through BMI1 repressive action on alternate tumor suppressor pathways that attempt to overcome INK4A/ARF/P53 inactivation and PI(3)K/AKT hyperactivity.
(Hori et al., 2003; Mammolenti et al., 2004; Ubiali et al., 2007). We found that BMI1 knockdown induced an upregulation of a large group of HLA class II molecules (and to a lesser extend class I molecules) (Table 1; supplemental Table, available at www.jneurosci.org as supplemental material). This is provocative since the malignancy and invasion capacity of GBM cells can to some extent be ascribed to their ability to effectively evade the immune system (by downregulation of HLA class I and class II molecules) (Facoetti et al., 2005; Zagzag et al., 2005). This suggests that BMI1 may allow GBM tumor cells to be undetectable by the host immune system through maintenance of a low immunogenic stem cell-like phenotype. BMI1 may thus confer GBM cells immune evasion either by preventing stem cell differentiation or through direct repression of HLA genes expression.

We also found that BMI1 knockdown induces an upregulation of transcripts involved in neurogenesis and gliogenesis, and this is supported by our in vitro observations revealing increased neural and gain-of-function activity may contribute to cell transformation. In this context, classical oncogenes overexpressed in GBM (such as $M Y C$ or $R A S$ ) and anti-oncogenes deleted or mutated in GBM (such as P53, NF1 or PTEN) may be responsible for regulating BMI1 expression levels. For example, C-MYC has been shown to positively regulate BMI1 expression in the NIH3T3 cell line with doxycycline-inducible expression of the FoxM1c transcription factor (Li et al., 2008). In turn, p53 and Pten codeletion results in glioma formation in mice because of dramatic upregulation of $c$-myc in astrocytes and neural stem cells (Zheng et al., 2008). Chromosomal aberrations may also account for BMI1 upregulation, as reported for a patient with T-cell acute lymphoblastic leukemia (Larmonie et al., 2008).

\section{BMI1 in glioma subtypes}

Knockdown of BMI1 or EZH2 had a significant effect on GBM cell growth in 4 independent cell lines. A similar response was observed with an astrocytoma grade III tumor sample. In contrast, an oligodendroma tumor sample was resistant to BMI1 knockdown and was modestly affected by EZH2 knockdown (supplemental Fig. 2, available at www.jneurosci.org as supplemental material). Gliomas are classified histologically, immunohistochemically and ultrastructurally as astrocytomas (graded from pilocytic astrocyma; grade I, to the most aggressive glioblastoma; grade IV), or oligodendromas (Maher et al., 2001). However, oligodendromas represent a distinct subtype of gliomas, possibly having a different cell of origin then astrocytoma and GBM. This may explain the selective dependency of GBM over PcG proteins. Alternatively, the mutational profile of each tumor, independently of its subtype, may determine PcG proteins dependency.

\section{BMI1 prevents immunogenicity and differentiation of GBM stem cells}

Neural stem cells are recognized to have a low immunogenic potential, in part because they do not express HLA molecules glial cell differentiation. This possibility is further supported by the downregulation of CD133/PROMININ and MUSASHI expression on BMI1 knockdown. Our data support the idea that BMI1 is required to maintain the undifferentiated state and selfrenewal capacity of cancer initiating cells in the tumor bulk.

BMI1 prevents cell cycle exit and apoptosis of GBM stem cells Recently, a meta-analysis performed with hundreds of independent GBM tumors revealed that combined coinactivation of 3 major oncogenic pathways is required for GBM tumor formation. This includes the ARF/MDM2/P53, P15 ${ }^{\mathrm{INK} 4 \mathrm{~B}} / \mathrm{P} 16^{\mathrm{INK} 4 \mathrm{~A}}$ / $\mathrm{P} 18^{\mathrm{INK} 4 \mathrm{C}} / \mathrm{RB}$ and RAS/PI(3)K/AKT pathways (CGAR, 2008). BMI1 functions are mainly attributed to its repressive action on the INK4A/ARF locus and on P53 activity (Jacobs et al., 1999a; Chatoo et al., 2009). The INK4A/ARF locus operates upstream of $\mathrm{P} 53$ and $\mathrm{RB}$. In this regards, it is notable that INK4A/ARF is deleted in $\geq 50 \%$ of GBM tumors and that $P 53$ is mutated in $35 \%$ of GBM tumors (CGAR, 2008). Notably, Bmil oncogenic function in transformed murine astrocytes is independent of a functional Ink4a/Arf locus (Bruggeman et al., 2007). To identify possible alternate tumor suppressor pathways, we thus used two glioma cell lines having homozygous deletions of the INK4A/ARF locus and performed gene expression profile analyses. We found that $P 21^{C i p}$ transcripts were upregulated after BMI1 knockdown, and our ChIP assays suggest that $P 21^{C i P}$ repression by BMI1 is direct. $P 21^{C i p}$ is a direct positive target of $\mathrm{P} 53$, and $\mathrm{P} 21^{\mathrm{Cip}}$ inhibits cell growth and the RB pathway by blocking CDK4/CDK6 activity. BMI1 may also directly repress FOXOA3 expression (table 1). FOXOA3, a potent inducer of apoptosis in cancer cells, is deleted in some GBM tumors, and is inhibited by activated AKT (Greer and Brunet, 2005; Jagani et al., 2008). P18 ${ }^{I N K 4 C}$ was shown to compensate for $P 16^{I N K 4 A}$ deletion in gliomas (Ramsey et al., 2007; Wiedemeyer et al., 2008). $P 16^{I N K 4 A}$ and $P 18^{I N K 4 C}$ operate upstream of RB to block cell cycle progression (Cánepa et al., 2007; Maddika et al., 2007). Notably, codeletion of $P 18^{I N K 4 C}$ in $P 16^{I N K 4 A}$-null gliomas significantly increases tumorigenicity, 
whereas functional reconstitution of $P 18^{I N K 4 C}$ in $P 18^{I N K 4 C /}$ $P 16^{I N K 4 A}$ double-mutant GBM cells impairs cell cycle progression and clonogenic potential (Wiedemeyer et al., 2008). We found that $P 18^{I N K 4 C}$ is upregulated after BMI1 knockdown in INK4A/ARF deleted GBM tumors, suggesting that repression of this locus is critical for BMI1 oncogenic function (Table 1). Together, these observations account for BMI1 requirement in GBM stem cell proliferation and survival. They also allow us to suggest a model in which GBM-tumors dependency over BMI1 is mediated through its repressive action on alternate tumor suppressor pathways that attempt to overcome INK4A/ARF/P53 inactivation and PI(3)K/AKT hyperactivity (Fig. $8 C$, see model). Because there is evidence that Bmil can also repress $p 21^{C i p 1} \mathrm{ex}-$ pression in normal stem cells (Fasano et al., 2007), not all BMI1 activities ascribed here in GBM cells necessarily represent gain-of-functions.

\section{$\mathrm{EZH} 2$ in brain tumors}

Our data are the first to reveal a direct involvement of EZH2 in human GBM. These observations would justify more intensive investigations of EZH2 role in glioblastoma tumors since inhibitors of histone methyltransferase already exist and could represent a new therapeutic approach. Notably, a cancer-specific complex (PRC4) containing EZH2, EED, SUZ12 and SIRT1, a deacetylase, has been isolated in transformed cells lines, and SIRT1 knockdown increases radio-sensitivity of CD133-positive glioma cells (Chang et al., 2009). This raises the issue of whether EZH2 forms a complex with SIRT1 in GBM cells and whether increase PcG proteins expression levels in GBM leads to the formation of new molecular complexes having biochemical activities not present in normal cells.

In conclusion, increasing evidence pointed out that brain malignancies originate from and contain cancer stem cells expressing the cell surface marker CD133 (Hemmati et al., 2003; Singh et al., 2004). We found that BMI1 and EZH2 are highly expressed in $\mathrm{CD}_{133^{+}} \mathrm{GBM}$ stem cells and required to sustain their selfrenewal. PcG proteins thus orchestrate important aspects of cancer stem cell biology and could represent prime molecular targets to cure glioma patients.

\section{References}

Alkema MJ, van der Lugt NM, Bobeldijk RC, Berns A, van Lohuizen M (1995) Transformation of axial skeleton due to overexpression of bmi-1 in transgenic mice. Nature 374:724-727.

Beà S, Tort F, Pinyol M, Puig X, Hernández L, Hernández S, Fernandez PL, van Lohuizen M, Colomer D, Campo E (2001) BMI-1 gene amplification and overexpression in hematological malignancies occur mainly in mantle cell lymphomas. Cancer Res 61:2409-2412.

Bruggeman SW, Valk-Lingbeek ME, van der Stoop PP, Jacobs JJ, Kieboom K, Tanger E, Hulsman D, Leung C, Arsenijevic Y, Marino S, van Lohuizen M (2005) Ink4a and Arf differentially affect cell proliferation and neural stem cell self-renewal in Bmil-deficient mice. Genes Dev 19:1438-1443.

Bruggeman SW, Hulsman D, Tanger E, Buckle T, Blom M, Zevenhoven J, van Tellingen O, van Lohuizen M (2007) Bmil Controls Tumor Development in an Ink4a/Arf-Independent Manner in a Mouse Model for Glioma. Cancer Cell 12:328-341.

Calabrese C, Poppleton H, Kocak M, Hogg TL, Fuller C, Hamner B, Oh EY, Gaber MW, Finklestein D, Allen M, Frank A, Bayazitov IT, Zakharenko SS, Gajjar A, Davidoff A, Gilbertson RJ (2007) A perivascular niche for brain tumor stem cells. Cancer Cell 11:69-82.

Cánepa ET, Scassa ME, Ceruti JM, Marazita MC, Carcagno AL, Sirkin PF, Ogara MF (2007) INK4 proteins, a family of mammalian CDK inhibitors with novel biological functions. IUBMB Life 59:419-426.

[CGAR] The Cancer Genome Atlas Research Network (2008) Comprehensive genomic characterization defines human glioblastoma genes and core pathways. Nature 455:1061-1068.
Chang CJ, Hsu CC, Yung MC, Chen KY, Tzao C, Wu WF, Chou HY, Lee YY, Lu KH, Chiou SH, Ma HI (2009) Enhanced radiosensitivity and radiation-induced apoptosis in glioma CD133-positive cells by knockdown of SirT1 expression. Biochem Biophys Res Commun 380:236-242.

Chatoo W, Abdouh M, David J, Champagne MP, Ferreira J, Rodier F, Bernier G (2009) The polycomb group gene Bmil regulates antioxidant defenses in neurons by repressing p53 pro-oxidant activity. J Neurosci 29:529-542.

Christianson SW, Greiner DL, Hesselton RA, Leif JH, Wagar EJ, Schweitzer IB, Rajan TV, Gott B, Roopenian DC, Shultz LD (1997) Enhanced human $\mathrm{CD} 4{ }^{+} \mathrm{T}$ cell engraftment in beta2-microglobulon-deficient NODscid mice. J Immunol 158:3578-3586.

Dellino GI, Schwartz YB, Farkas G, McCabe D, Elgin SC, Pirrotta V (2004) Polycomb silencing blocks transcription initiation. Mol Cell 13:887-893.

Dimri GP, Martinez JL, Jacobs JJ, Keblusek P, Itahana K, Van Lohuizen M, Campisi J, Wazer DE, Band V (2002) The Bmi-1 oncogene induces telomerase activity and immortalizes human mammary epithelial cells. Cancer Res 62:4736-4745.

Facoetti A, Nano R, Zelini P, Morbini P, Benericetti E, Ceroni M, Campoli M, Ferrone S (2005) Human leukocyte antigen and antigen processing machinery component defects in astrocytic tumors. Clin Cancer Res 11:8304-8311.

Fasano CA, Dimos JT, Ivanova NB, Lowry N, Lemischka IR, Temple S (2007) shRNA knockdown of Bmi-1 reveals a critical role for p21-Rb pathway in NSC self-renewal during development. Cell Stem Cell 1:87-99.

Galli R, Binda E, Orfanelli U, Cipelletti B, Gritti A, De Vitis S, Fiocco R, Foroni C, Dimeco F, Vescovi A (2004) Isolation and characterization of tumorigenic, stem-like neural precursors from human glioblastoma. Cancer Res 64:7011-7021.

Greer EL, Brunet A (2005) FOXO transcription factors at the interface between longevity and tumor suppression. Oncogene 24:7410-7425.

Hanson RD, Hess JL, Yu BD, Ernst P, van Lohuizen M, Berns A, van der Lugt NM, Shashikant CS, Ruddle FH, Seto M, Korsmeyer SJ (1999) Mammalian trithorax and polycomb-group homologues are antagonistic regulators of homeotic development. Proc Natl Acad Sci U S A 96:14372-14377.

Haupt Y, Alexander WS, Barri G, Klinken SP, Adams JM (1991) Novel zinc finger gene implicated as myc collaborator by retrovirally accelerated lymphomagenesis in E mu-myc transgenic mice. Cell 65:753-763.

Hemmati HD, Nakano I, Lazareff JA, Masterman-Smith M, Geschwind DH, Bronner-Fraser M, Kornblum HI (2003) Cancerous stem cells can arise from pediatric brain tumors. Proc Natl Acad Sci U S A 100:15178-15183.

Holland EC (2001) Gliomagenesis: genetic alterations and mouse models. Nat Rev Genet 2:120-129.

Hori J, Ng TF, Shatos M, Klassen H, Streilein JW, Young MJ (2003) Neural progenitor cells lack immunogenicity and resist destruction as allografts. Stem Cells 21:405-416.

Ivanova N, Dobrin R, Lu R, Kotenko I, Levorse J, DeCoste C, Schafer X, Lun Y, Lemischka IR (2006) Dissecting self-renewal in stem cells with RNA interference. Nature 442:533-538.

Jacobs JJ, Kieboom K, Marino S, DePinho RA, van Lohuizen M (1999a) The oncogene and Polycomb-group gene bmi-1 regulates cell proliferation and senescence through the ink4a locus. Nature 397:164-168.

Jacobs JJ, Scheijen B, Voncken JW, Kieboom K, Berns A, van Lohuizen M (1999b) Bmi-1 collaborates with c-Myc in tumorigenesis by inhibiting c-Myc-induced apoptosis via INK4a/ARF. Genes Dev 13:2678-2690.

Jagani Z, Singh A, Khosravi-Far R (2008) FoxO tumor suppressors and BCR-ABL-induced leukemia: a matter of evasion of apoptosis. Biochim Biophys Acta 1785:63-84.

Kim JH, Yoon SY, Jeong SH, Kim SY, Moon SK, Joo JH, Lee Y, Choe IS, Kim JM (2004) Overexpression of Bmi-1 oncoprotein correlates with axillary lymph node metastases in invasive ductal breast cancer. Breast 13:383388.

Kleer CG, Cao Q, Varambally S, Shen R, Ota I, Tomlins SA, Ghosh D, Sewalt RG, Otte AP, Hayes DF, Sabel MS, Livant D, Weiss SJ, Rubin MA, Chinnaiyan AM (2003) EZH2 is a marker of aggressive breast cancer and promotes neoplastic transformation of breast epithelial cells. Proc Natl Acad Sci U S A 100:11606-11611.

Larmonie NS, Dik WA, Beverloo HB, van Wering ER, van Dongen JJ, Langerak AW (2008) BMIl as oncogenic candidate in a novel TCRBassociated chromosomal aberration in a patient with TCRgammadelta ${ }^{+}$ T-cell acute lymphoblastic leukemia. Leukemia 22:1266-1267.

Lassman AB, Dai C, Fuller GN, Vickers AJ, Holland EC (2004) Overexpres- 
sion of c-MYC promotes an undifferentiated phenotype in cultured astrocytes and allows elevated Ras and Akt signaling to induce gliomas from GFAP-expressing cells in mice. Neuron Glia Biol 1:157-163.

Lee TI, Jenner RG, Boyer LA, Guenther MG, Levine SS, Kumar RM, Chevalier B, Johnstone SE, Cole MF, Isono K, Koseki H, Fuchikami T, Abe K, Murray HL, Zucker JP, Yuan B, Bell GW, Herbolsheimer E, Hannett NM, Sun K, et al. (2006) Control of developmental regulators by Polycomb in human embryonic stem cells. Cell 125:301-313.

Lessard J, Sauvageau G (2003) Bmi-1 determines the proliferative capacity of normal and leukaemic stem cells. Nature 423:255-260.

Leung C, Lingbeek M, Shakhova O, Liu J, Tanger E, Saremaslani P, Van Lohuizen M, Marino S (2004) Bmil is essential for cerebellar development and is overexpressed in human medulloblastomas. Nature 428:337-341.

Levine SS, Weiss A, Erdjument-Bromage H, Shao Z, Tempst P, Kingston RE (2002) The core of the polycomb repressive complex is compositionally and functionally conserved in flies and humans. Mol Cell Biol 22:6070-6078.

Li SK, Smith DK, Leung WY, Cheung AM, Lam EW, Dimri GP, Yao KM (2008) FoxM1c counteracts oxidative stress-induced senescence and stimulates Bmi-1 expression. J Biol Chem 283:16545-16553.

Louis DN, Ohgaki H, Wiestler OD, Cavenee WK, Burger PC, Jouvet A, Scheithauer BW, Kleihues P (2007) The 2007 WHO classification of tumours of the central nervous system. Acta Neuropathol 114:97-109.

Maddika S, Ande SR, Panigrahi S, Paranjothy T, Weglarczyk K, Zuse A, Eshraghi M, Manda KD, Wiechec E, Los M (2007) Cell survival, cell death and cell cycle pathways are interconnected: implications for cancer therapy. Drug Resist Updat 10:13-29.

Maher EA, Furnari FB, Bachoo RM, Rowitch DH, Louis DN, Cavenee WK, DePinho RA (2001) Malignant glioma: genetics and biology of a grave matter. Genes Dev 15:1311-1333.

Mammolenti M, Gajavelli S, Tsoulfas P, Levy R (2004) Absence of major histocompatibility complex class I on neural stem cells does not permit natural killer cell killing and prevents recognition by alloreactive cytotoxic T lymphocytes in vitro. Stem Cells 22:1101-1110.

Molofsky AV, Pardal R, Iwashita T, Park IK, Clarke MF, Morrison SJ (2003) Bmi-1 dependence distinguishes neural stem cell self-renewal from progenitor proliferation. Nature 425:962-967.

Molofsky AV, He S, Bydon M, Morrison SJ, Pardal R (2005) Bmi-1 promotes neural stem cell self-renewal and neural development but not mouse growth and survival by repressing the p16Ink4a and p19Arf senescence pathways. Genes Dev 19:1432-1437.

Ohgaki H, Kleihues P (2007) Genetic pathways to primary and secondary glioblastoma. Am J Pathol 170:1445-1453.

Orian JM, Vasilopoulos K, Yoshida S, Kaye AH, Chow CW, Gonzales MF (1992) Overexpression of multiple oncogenes related to histological grade of astrocytic glioma. Br J Cancer 66:106-112.

Park IK, Qian D, Kiel M, Becker MW, Pihalja M, Weissman IL, Morrison SJ, Clarke MF (2003) Bmi-1 is required for maintenance of adult selfrenewing haematopoietic stem cells. Nature 423:302-305.

Ramsey MR, Krishnamurthy J, Pei XH, Torrice C, Lin W, Carrasco DR, Ligon KL, Xiong Y, Sharpless NE (2007) Expression of p16Ink4a compensates for p18Ink4c loss in cyclin-dependent kinase 4/6-dependent tumors and tissues. Cancer Res 67:4732-4741.

Singh SK, Clarke ID, Terasaki M, Bonn VE, Hawkins C, Squire J, Dirks PB (2003) Identification of a cancer stem cell in human brain tumors. Cancer Res 63:5821-5828.

Singh SK, Hawkins C, Clarke ID, Squire JA, Bayani J, Hide T, Henkelman RM, Cusimano MD, Dirks PB (2004) Identification of human brain tumour initiating cells. Nature 432:396-401.
Sparmann A, van Lohuizen (2006) Polycomb silencers control cell fate, development and cancer. Nature Rev 6:846-856.

Ubiali F, Nava S, Nessi V, Frigerio S, Parati E, Bernasconi P, Mantegazza R, Baggi F (2007) Allorecognition of human neural stem cells by peripheral blood lymphocytes despite low expression of MHC molecules: role of TGF-beta in modulating proliferation. Int Immunol 19:1063-1074.

Valk-Lingbeek ME, Bruggeman SW, van Lohuizen M (2004) Stem cells and cancer; the polycomb connection. Cell 118:409-418.

van der Lugt NM, Alkema M, Berns A, Deschamps J (1996) The Polycombgroup homolog Bmi-1 is a regulator of murine Hox gene expression. Mech Dev 58:153-164.

van Kemenade FJ, Raaphorst FM, Blokzijl T, Fieret E, Hamer KM, Satijn DP, Otte AP, Meijer CJ (2001) Coexpression of BMI-1 and EZH2 Polycomb-group proteins is associated with cycling cells and degree of malignancy in B-cell non-Hodgkin lymphoma. Blood 97:3896-3901.

van Lohuizen M, Verbeek S, Scheijen B, Wientjens E, van der Gulden H, Berns A (1991) Identification of cooperating oncogenes in E mu-myc transgenic mice by provirus tagging. Cell 65:737-752.

Varambally S, Dhanasekaran SM, Zhou M, Barrette TR, Kumar-Sinha C, Sanda MG, Ghosh D, Pienta KJ, Sewalt RG, Otte AP, Rubin MA, Chinnaiyan AM (2002) The Polycomb group protein EZH2 is involved in progression of prostate cancer. Nature 419:624-629.

Vecchi A, Garlanda C, Lampugnani MG, Resnati M, Matteucci C, Stoppacciaro A, Schnurch H, Risau W, Ruco L, Mantovani A (1994) Monoclonal antibodies specific for endothelial cells of mouse blood vessels. Their application in the identification of adult and embryonic endothelium. Eur J Cell Biol 63:247-254.

Visser HP, Gunster MJ, Kluin-Nelemans HC, Manders EM, Raaphorst FM, Meijer CJ, Willemze R, Otte AP, Visser HP, et al. (2001) The Polycomb group protein $\mathrm{EZH} 2$ is upregulated in proliferating, cultured human mantle cell lymphoma. Br J Haematol 112:950-958.

Vonlanthen S, Heighway J, Altermatt HJ, Gugger M, Kappeler A, Borner MM, van Lohuizen M, Betticher DC (2001) The bmi-1 oncoprotein is differentially expressed in non-small cell lung cancer and correlates with INK4A-ARF locus expression. Br J Cancer 84:1372-1376.

Wang L, Brown JL, Cao R, Zhang Y, Kassis JA, Jones RS (2004) Hierarchical recruitment of polycomb group silencing complexes. Mol Cell 14:637-646.

Wiedemeyer R, Brennan C, Heffernan TP, Xiao Y, Mahoney J, Protopopov A, Zheng H, Bignell G, Furnari F, Cavenee WK, Hahn WC, Ichimura K, Collins VP, Chu GC, Stratton MR, Ligon KL, Futreal PA, Chin L (2008) Feedback circuit among INK4 tumor suppressors constrains human glioblastoma development. Cancer Cell 13:355-364.

Yuan X, Curtin J, Xiong Y, Liu G, Waschsmann-Hogiu S, Farkas DL, Black $\mathrm{KL}$, Yu JS (2004) Isolation of cancer stem cells from adult glioblastoma multiforme. Oncogene 23:9392-9400.

Zagzag D, Salnikow K, Chiriboga L, Yee H, Lan L, Ali MA, Garcia R, Demaria S, Newcomb EW (2005) Downregulation of major histocompatibility complex antigens in invading glioma cells: stealth invasion of the brain. Lab Invest 85:328-341.

Zencak D, Lingbeek M, Kostic C, Tekaya M, Tanger E, Hornfeld D, Jaquet M, Munier FL, Schorderet DF, van Lohuizen M, Arsenijevic Y (2005) Bmil loss produces an increase in astroglial cells and a decrease in neural stem cell population and proliferation. J Neurosci 25:5774-5783.

Zheng H, Ying H, Yan H, Kimmelman AC, Hiller DJ, Chen AJ, Perry SR, Tonon G, Chu GC, Ding Z, Stommel JM, Dunn KL, Wiedemeyer R, You MJ, Brennan C, Wang YA, Ligon KL, Wong WH, Chin L, DePinho RA (2008) p53 and Pten control neural and glioma stem/progenitor cell renewal and differentiation. Nature 455:1129-1133. 